\title{
REPORT
}

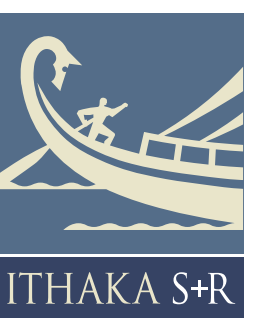

\section{Supporting the Changing Research Practices of Religious Studies Scholars}

February 8, 2017

Danielle Cooper

Roger Schonfeld

$\begin{array}{lll}\text { Richard Adams } & \text { Trevan Hatch } & \text { Kay Roethemeyer } \\ \text { Matthew Baker } & \text { Justin Hill } & \text { Robert Roethemeyer } \\ \text { Nisa Bakkalbasi } & \text { Bill Hook } & \text { Ramona Romero } \\ \text { John G. Bales } & \text { Thad Horner } & \text { Fred Rowland } \\ \text { Rebekah Bedard } & \text { Hye-jin Juhn } & \text { Veronica Simms } \\ \text { Chris Benda } & \text { Andrew Keck } & \text { Kate Skrebutenas } \\ \text { Beth Bidlack } & \text { Michael Kohut } & \text { Jacqueline Solis } \\ \text { Sarah Bogue } & \text { Gloria Korsman } & \text { Steven Squires } \\ \text { Trisha Burr } & \text { Graziano Krätli } & \text { Maria Stanton } \\ \text { Gillian Harrison Cain } & \text { Ryan Lee } & \text { Naomi Steinberger } \\ \text { InaCohen } & \text { Rebecca Lloyd } & \text { Chris Strauber } \\ \text { Wesley Custer } & \text { Reed Lowrie } & \text { Elka Tenner } \\ \text { Virginia Dearborn } & \text { Margot Lyon } & \text { Amanda Thomas } \\ \text { Gerritvan Dyk } & \text { Jean McManus } & \text { Paul Allen Tippey } \\ \text { Suzanne Estelle-Holmer } & \text { John Meeks } & \text { Nancy Turner } \\ \text { Kathryn Flynn } & \text { Christine Pesch Richardson Nicholas Weiss } \\ \text { Jenifer Gundry } & \text { John Robinson } & \end{array}$




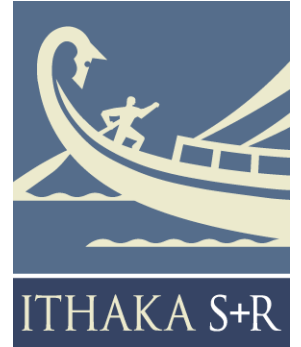

Ithaka $\mathrm{S}+\mathrm{R}$ is a strategic consulting and research service provided by ITHAKA, a not-for-profit organization dedicated to helping the academic community use digital technologies to preserve the scholarly record and to advance research and teaching in sustainable ways. Ithaka $\mathrm{S}+\mathrm{R}$ focuses on the transformation of scholarship and teaching in an online environment, with the goal of identifying the critical issues facing our community and acting as a catalyst for change. JSTOR, a research and learning platform, and Portico, a digital preservation service, are also part of ITHAKA.
Copyright 2017 ITHAKA. This work is licensed under a Creative Commons Attribution-NonCommercial 4.0 International License. To view a copy of the license, please see http://creativecommons.org/licenses/by-nc/4.0/.

ITHAKA is interested in disseminating this brief as widely as possible. Please contact us with any questions about using the report: research@ithaka.org. 
We dedicate this report to the memory of Donald Vorp, who was a great supporter of the Research Support Services project on Religious Studies and a champion of theological librarianship.

We thank the American Theological Library Association (ATLA) for its sponsorship of the Research Support Services project on Religious Studies. We are also grateful for the support of the American Academy of Religion (AAR) and Society of Biblical Literature (SBL).
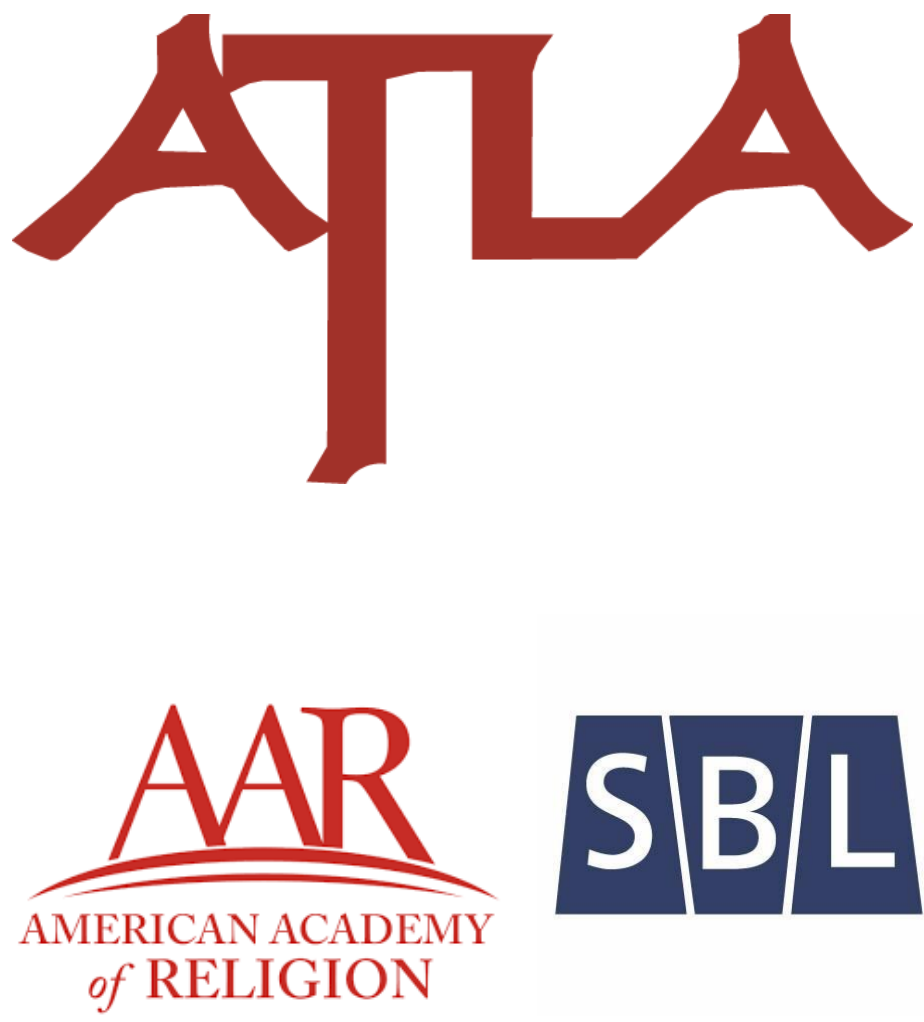

of RELIGION 


\section{Contents}

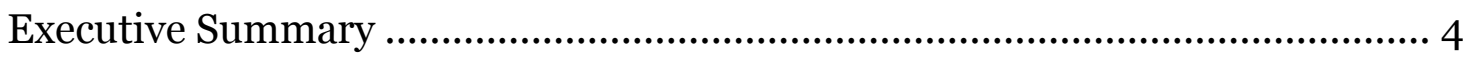

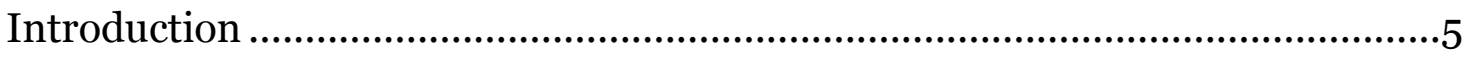

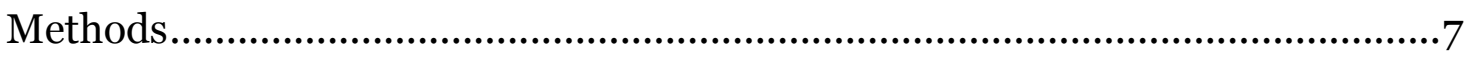

Discovering and Accessing Information ..............................................14

Information Management............................................................... 25

Audience, Output and Credit ........................................................... 30

Digital Humanities ................................................................................ 36

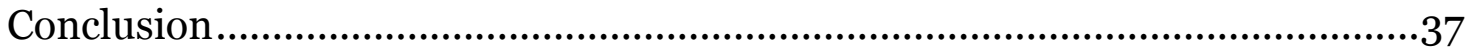

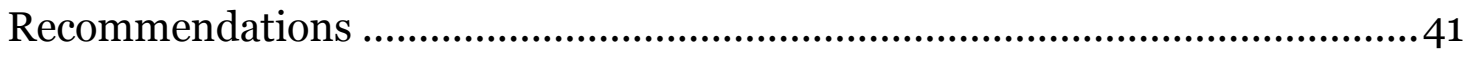

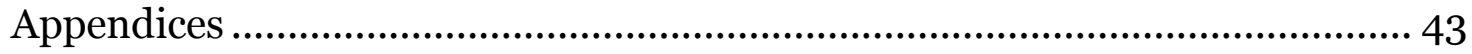




\section{Executive Summary}

Ithaka S+R's Research Support Services Program is a series of projects that investigate the research support needs of scholars by their discipline. In 2016 Ithaka $S+R$ examined the changing research methods and practices of academic religious studies scholars in the United States, with the goal of identifying services to better support them. The project was undertaken collaboratively with research teams at 18 academic libraries and the American Theological Library Association with guidance from an advisory committee.

The goal of this report is to provide actionable findings for the organizations, institutions and professionals who support the research process of religious studies. One hundred and ninety eight scholars were interviewed during the project and Ithaka $\mathrm{S}+\mathrm{R}$ sampled 102 of the resulting transcripts towards the analysis for this report. Ithaka $\mathrm{S}+\mathrm{R}$ identified three major thematic areas in which religious studies would benefit from improved or new services:

- Discovering and accessing information. When available, digital discovery and access have greatly improved these scholars' research experiences with relatively few challenges. Scholars located in some seminaries and those conducting research on religions and religious cultures beyond the West experience greater challenges when conducting primary and secondary source research.

- Information management. Scholars contend with the challenge of managing vast arrays of information that they produce and collect in the process of conducting their research and engage in idiosyncratic practices for organizing and storing their information. They struggle with digital approaches to citation management and information storage and experience uncertainty around destroying and preserving information following their personal use.

- Audience, output and credit. Scholars' primary focus remains on traditional scholarly outputs due to the expectations associated with tenure and promotion. Overall awareness and engagement with open access is low but the perceived importance of more freely sharing work as enabled by social media platforms is high.

The report concludes by highlighting key issues and providing recommendations from across the findings that have wider implications for how religious studies research support is conceptualized and prioritized. Religious studies scholars' ongoing lack of awareness of and engagement with digital research methods, including those associated with the digital humanities, reflects major structural barriers to methodological innovation within the discipline necessitating intervention at various levels. While religious studies scholars continue to rely on their institutional libraries, particularly for access to secondary materials, their use of the library is placed among many other strategies for finding and accessing information. Supporting religious studies scholars in 
their capacities as collectors is one entryway for re-thinking how research support can be cohesively defined and delineated.

\section{Introduction}

The contexts and practices of research in higher education are in great flux. Scholars are not only confronting new technologies that redefine every aspect of their research activity - from discovering to organizing to disseminating information - but they also must contend with the economic restructuring of the academy. As research activity evolves, so too must the services and spaces that are provided to foster those activities.

In order to better understand the changing research methods and practices, Ithaka S+R's Research Support Services (RSS) program conducts in-depth qualitative analysis of the research practices and associated support needs of scholars by discipline. Previous projects in the program explored scholars in history, chemistry and art history. ${ }^{1}$ Each project in the program fosters a scholar-centered approach to understanding research in higher education that will lead to new insights towards developing information services and spaces. The programmatic nature of this work also enables comparison of scholarly activity across the disciplines, which leads to deeper understanding of what makes research activity unique throughout the academy.

\section{The discipline includes a complex interplay of types of scholarship amidst a shifting backdrop of ongoing debates about the role and function of religion in higher education and the evolution of perception and practice of religion in society at large.}

Religious studies provided a compelling entry point for continuing this work. The discipline includes a complex interplay of types of scholarship amidst a shifting backdrop

\footnotetext{
1 Jennifer Rutner and Roger C. Schonfeld, "Supporting the Changing Research Practices of Historians," Ithaka $S+R$, December 10, 2012, http://dx.doi.org/10.18665/sr.22532; Matthew P. Long and Roger C. Schonfeld," "Supporting the Changing Research Practices of Chemists," Ithaka S+R, February 26, 2013, http://dx.doi.org/10.18665/sr.22561; Matthew P. Long and Roger C. Schonfeld," "Supporting the Changing Research Practices of Art Historians," Ithaka S+R, April 30, 2014, http://dx.doi.org/10.18665/sr.22833.
} 
of ongoing debates about the role and function of religion in higher education and the evolution of perception and practice of religion in society at large. Traditionally humanistic in orientation, social science methods are increasingly popular within the discipline, and there is also a move towards incorporating new approaches to interdisciplinary research. Across this methodological spectrum the discipline is contending with representational tensions, both in terms of the religions and geographic areas studied and who is conducting the research. Religious studies scholars may also approach their work from different positionalities: some take a "confessional" approach to their work (meaning, their work is in service to or support of a particular faith tradition) and/or they are oriented towards the professional dimension of religion (e.g. educating future pastors), while others articulate their work as having strictly secular and non-applied academic aims. Some standalone seminaries are facing major funding challenges, mergers and closures, while religious studies scholars also generally feel the threat of decline in funding and lack of tenure-track jobs.

An underlying concern of this project is how technological affordances are shaping research practices within the discipline. The majority of religious studies scholars reported that they experience benefits associated with increased discovery and access to information for both primary and secondary sources. However, their approach to seeking and analyzing this information remains largely under systematized and some struggle with even basic awareness of and skills using these tools. Despite the promise of new technology-enabled research methodologies and dissemination, such as those associated with digital humanities, the majority of scholars reported engaging in traditional research and publishing activities, in part due to an academic system that continues to privilege peer-reviewed book and journal publications. ${ }^{2}$ We learned that access to digital information is a challenge for scholars studying religion beyond the West and scholars located in institutions with funding constraints, such as standalone seminaries and historically black colleges and universities. ${ }^{3}$

Our report provides an overview of religious studies scholars' research activities across the life-cycle of their research from information discovery and access, to organization, preservation, and dissemination, and their perceptions of how the discipline is evolving

\footnotetext{
${ }^{2}$ The orientation of the majority of religious studies scholars to emerging technology-enabled research methodologies and dissemination is fairly consistent with the orientation of scholars in the humanities and social sciences more widely. For example, Ithaka S+R's US Faculty Survey 2015 found no overall growth in digital humanities research activity, see Christine Wolff, Alisa B. Rod and Roger C. Schonfeld, "Ithaka S+R US Faculty Survey 2015," Ithaka S+R, April 4, 2016, http://www.sr.ithaka.org/wp-content/uploads/2016/03/SR Report US Faculty Survey 201504416.pdf, 75.

${ }^{3}$ Challenges of accessing information due to funding constraints may also be experienced by scholars at types of institutions not represented in our sample, most notably, smaller liberal arts colleges, which warrants further research attending specifically to those institutional contexts.
} 
and the implications of those changes for how research is conducted. Throughout we attend to how the diversity in the types of religious studies scholars leads to convergences and divergences in their research practices. We hope that the findings and recommendations will suggest opportunities for the broader community that supports religious studies research.

\section{Methods}

This report is one component of a collaborative research project undertaken with 18 institutions in consultation with an advisory committee. A central component to developing the project was defining "religious studies scholar" and delimiting meaningful categories within the larger field for further analysis. Attending to representation, both in terms of participating institutions and, by extension, the scholars included in the research, were also of key concern.

\section{Developing the Religious Studies Project}

Ithaka $\mathrm{S}+\mathrm{R}$ convened an advisory committee and solicited input from several other religious studies librarians and scholars who are leaders in their fields to guide the project. We thank the advisory committee for their thoughtful participation in the project: Brenda Bailey-Hainer (American Theological Library Association), Jack Fitzmier (American Academy of Religion), John Kutsko (Society of Biblical Literature), and Sabahat Adil (University of Colorado Boulder). Patrick Graham (Pitts Theology Library, Emory University), Beth Bidlack (Burke Library at Union Theological Seminary), and Jacob Wright (Emory University) also provided helpful insight.

This project represents the first time Ithaka $S+R$ has worked collaboratively with other institutions to conduct in-depth research on a scholarly discipline. ${ }^{4}$ Eighteen academic libraries partnered with Ithaka $\mathrm{S}+\mathrm{R}$ and created research teams of one to four members who, following a training workshop designed and led by Danielle Cooper, collected the qualitative data that Ithaka $\mathrm{S}+\mathrm{R}$ analyzed for this report. Participation in the project was open to any U.S. higher education institution with religious studies offerings and able to conform to the project specifications (e.g. timeline, research capacity). We included all institutions that met this criteria and we thank all the institutions who were able to participate in the project. Appendix 1 lists the participants on the institutional research teams. Appendix 2 and 3 detail the demographic characteristics of the research teams'

\footnotetext{
${ }^{4}$ Research for our previous reports on the research support needs of scholars in art history, chemistry and history was conducted exclusively by Ithaka S+R staff.
} 
institutions, and Appendix 4 provides further information about those institutions' scopes and missions.

Once the initial expressions of interest were gathered, the American Theological Library Association did further outreach to specific institutions to ensure broader inclusion across the spectrum of religious studies in U.S. higher education. Of particular concern was enabling participation of standalone seminaries and institutions with scholars that study religions beyond Christianity. A portion of the sponsorship provided by the American Theological Library Association enabled the inclusion of institutions that would otherwise have been unable to participate due to financial barriers and thus diversified participation. The American Theological Library Association also participated by conducting interviews with two groups that remained underrepresented within the cohort of participating institutions and were identified as priorities for inclusion: scholars of Islam and scholars from historically black colleges and universities. This resulted in interviews with scholars at the following institutions: Howard University, Interdenominational Theological Center, Spelman College, Clark Atlanta University, University of Colorado Boulder, and University of Oklahoma. Appendix 3 details the demographic characteristics of the institutions included through the interviews conducted by the American Theological Library Association.

The research teams at the participating institutions primarily comprised subject librarians but also included participants in other roles such as acquisitions and collections librarians, digital and web services librarians, and graduate students. Each team conducted research with a target of 15 religious studies scholars at their institution through semi-structured interviews that followed the arc of the research process (see Appendix 6 for the interview guide). Research teams also had the option of using photography to document noteworthy information, collections, and spaces. Each team also developed their own analysis from the data they collected at their respective institutions with the option of either creating an internal whitepaper or a publicly available report. The publicly available local reports, which provide a compliment to this capstone report, are listed and linked in Appendix 5.

Ithaka $\mathrm{S}+\mathrm{R}$ collected anonymized transcripts from each participating institution and interviews from the American Theological Library Association for a total sample of 102 interviews towards the analysis for this report. The transcripts were selected purposively to ensure maximum variation in interviewee demographics as per their institutional affiliations, methodological approaches, and topics of study (with emphasis on ensuring that research beyond Western mainline Christianity was meaningfully included). The transcripts were analyzed through a grounded approach to coding utilizing NVivo 
software. The interviewees remain unidentified in this report to protect anonymity and we thank them for their participation.

\section{Defining and Delimiting the Religious Studies Scholar}

The project focuses on the practices and needs of religious studies scholars exclusively in the context of higher education. Reflecting the project's aim to focus on research as opposed to teaching activities, we defined "scholars" as individuals who are employed by their institutions with research as a significant component of their capacity, as opposed to primarily teaching. Graduate students were also not included in this study. ${ }^{5}$

The definition of religious studies used for this project reflects the breadth and diversity of the discipline. Scholars who study religion examine a variety of time periods, world regions, and religious traditions. They use methods such as linguistics, anthropology, history, philosophy, textual criticism, sociology, and political science. They may be found in academia in arts and sciences departments such as religious studies, philosophy, anthropology, history, and sociology as well as in centers for training and practice such as divinity schools and seminaries. Some scholars contribute to the professional training of religious leaders, while others study these topics from a purely secular perspective. In this project, we did not focus on any particular religion.

The boundaries of what constitutes religious studies is at times contested, in particular, the relationship between theology and religious studies. ${ }^{6}$ While the focus of the project was not to track religious studies scholars' perspectives on the relationship between religious studies and theology, we did attend to this issue to determine whether these divisions were relevant to research support activities or needs or perceptions of the discipline more widely. Overall, scholars in this project either identified as being firmly part of religious studies and/or they did not object to their work being included under the larger umbrella of religious studies. Some highlighted that there was a false dichotomy between the two terms, that they were unaware of the difference, or that they preferred to avoid the debate. Others aligned with Islamic studies and Jewish studies highlighted that they identified more with those areas than "religious studies" or "theology" due to the historic Christian-centrism of those fields. In lieu of the term

\footnotetext{
${ }^{5}$ While research is also a major activity for graduate students, we left graduate students out of scope because the context in which they conduct their research and their relationship to their institutions is different enough to warrant their exclusion.

${ }^{6}$ See for example: Tara Isabella Burton, “The End of Theology?" Chronicle of Higher Education, January 24, 2016, https://shar.es/1lvdZI, and, Linell E. Cady and Delwin Brown, Religious Studies, Theology, and the University: Conflicting Maps, Changing Terrain (Albany: SUNY Press, 2002).
} 
theology, some scholars also highlighted the difference between "confessional" or "nonconfessional" research (whether or not one conducts scholarship from the perspective of or in service of a particular faith tradition or church).

\section{Categorizing the Religious Studies Scholar}

Ithaka $\mathrm{S}+\mathrm{R}$ carefully attended to scholars' methodological orientations to ensure that scholars with a variety of approaches to the field were included in the analysis and that those differences were considered, when relevant, to identifying research support needs and services. Religious studies is traditionally an interdisciplinary humanistic pursuit. 7 While there are anecdotal perceptions that social science approaches are increasingly popular within the field, these approaches primarily fall within the bounds of the "humanistic social sciences." As such, many religious studies scholars share similarities in their research approaches and these approaches often overlap with the activities and concerns of scholars in other humanistic disciplines. However, some areas of study aligned with religious studies, most notably theology and biblical studies, have sufficiently meaningful histories and contemporary scholarly cultures to warrant further attention within the report. Furthermore, social science researchers in religious studies rely on qualitative research methods that distinguish some of their research support needs from their peers located in the humanities proper. Finally, scholars whose work explores the arts of ministry towards benefitting professional training fall within the methodological bounds of applied research that warrants analysis separate from the other categories.

Based on these considerations Ithaka $\mathrm{S}+\mathrm{R}$ created the following categories to distinguish between scholars when determining which interviews to include in the sample: humanities, biblical studies, theology, social science, and arts of ministry. When relevant, differences between categories that emerged during the analysis process are noted in the report. The categories are not considered mutually exclusive and do not represent a hierarchy of research approaches within religious studies. How various scholars define themselves and others as falling within or outside the bounds of religious studies is beyond the scope of this project. What follows below are detailed descriptions of the categories, and, demographic information about scholars placed within these categories and how they relate to the sample as a whole.

${ }^{7}$ The definition of what constitutes religious studies as a humanistic pursuit varies. For example, the American Academy of Arts and Science includes "religion" within the scope of "humanities" for the purposes of its Humanities Indicators as "programs in the comparative, nonsectarian study of religion; studies of particular religions; history of religion; does not include programs in theology or ministry" but also acknowledges that some institutions "count all theology and ministry courses as humanities instruction." 


\section{Humanities}

In this study "humanities" refers to scholars who utilize humanities research methods such as art history, history, and philosophy, among many others. Biblical studies and theology scholars also fit within the purview of the humanities but were selected in addition to this category in order to examine and attend to the unique context of those fields in relation to religious studies. This category represented the largest proportion of scholars collected across the participating institutions. Ithaka S+R selected thirty five scholars that conformed to this category for further analysis.

The majority of humanities scholars in this study had affiliations (and cross-affiliations) in non-professional departments such as religion, classics, or history (among others). As per the recommendations of the advisory committee, Ithaka $S+R$ selected all of the scholars who were cross-listed between their university's religious studies departments and their university's seminary, divinity or theology school or department, and the four of whom this designation applied are humanists.

Religious studies scholars in the humanities draw from a variety of disciplines to do their work including American studies, history, literature, linguistics, art history, and classics. The majority of scholars in the sample identified either as historians or noted that their work involved history-inflected methodologies, including intellectual history, social history, and oral history. The majority of these religious studies scholars primarily received their training in other disciplines (as opposed to religious studies) and closely identify with those fields. They attend conferences in these other disciplines and many reported that they became involved in religious studies only after their appointment in a religious studies department. Some continued to see their work as primarily falling in another discipline, while seeing only the content of their work as aligned with religious studies. No scholars in this cohort conceptualized their work in terms of theology as opposed to religious studies, but one interviewee in a divinity school did report that their work fit into that program because of interest in larger issues of "practical" ethics.

These scholars' theoretical approaches were mixed. Some noted that history in particular does not require theoretical frameworks like other humanities disciplines. Typical responses to theoretical approaches in this group included: "that's always a tough question for a historian"; "historians are very nervous about hewing to a particular line or ideology, although there are Marxist historians and liberal historians and so forth and so on"; and "[my work] does not overtly employ theoretical structures. I'm one of those historians." Yet, others did note that their research is informed by theoretical frameworks, such as feminist, post-colonial, and postmodern. 


\section{Biblical Studies}

Biblical studies, which is the academic study of the Bible from various disciplinary perspectives, represents an important field of humanistic inquiry within religious studies warranting particular attention for this report. Twenty biblical studies scholars were selected in addition to scholars counted in the humanities category above.

Biblical studies scholars draw on artifacts and texts that illuminate the context and meaning of the Bible relying on methodologies that are generally historical (e.g. intellectual history, historical-critical, reception history, discourse analysis), literary (e.g. narrative criticism, textual analysis, or linguistic (e.g. philology, sociolinguistics) in nature, often in combination. These scholars often report engaging with adjacent disciplines such as archaeology, classics, and near and Middle Eastern studies. In the last several decades the field has dramatically expanded to include contextual interpretations and the social impact of biblical traditions, and these scholars engage heavily in cultural studies. Scholars may approach biblical studies from either a secular or confessional approach and can be found in religious studies departments as well as seminaries, theology and divinity departments or schools. Regardless of how they read their texts, as determined by their disciplinary and theoretical alignments, biblical studies scholars generally display a shared practice of closely reading texts. Their research practices also display commonalities because the discipline is united by a canon of primary source texts, although they often specialize within that canon, or specialize on contemporaneous ancient texts outside the biblical canon

\section{Theology}

"Theology" refers to the critical study of the nature of the divine, which may or may not be a confessional practice deliberately tied to a particular church or faith tradition. ${ }^{8}$ Fourteen scholars aligned with theology were selected for this report in addition to the scholars selected in the humanities category in recognition of the field's unique history and complex relationship to religious studies. Reflecting the term's origin within Western thought traditions, applying the term to studying belief systems beyond Judaism and Christianity is contested. Within the sample for this study the majority of the fourteen theology scholars were focused primarily on Judeo and/or Christian texts, with one scholar focused on Buddhism.

Scholars aligned with theology engage with other disciplines, but the nature of engagement varies by whether they are more oriented towards historical methods or

\footnotetext{
${ }^{8}$ This project categorizes "practical theology" alongside other applied scholarship within the "arts of ministry" category.
} 
textual, systematic, and/or thematic analysis. Those who are oriented to studying theology thematically characterized the work in such ways as "read[ing] my way into a topic," "putting texts into conversation," and working to see "where other discourses put pressure on theology." Scholars oriented more with history tend to concurrently engage with the disciplines or area studies aligned with the context of their primary texts, such as Buddhist Studies, medieval studies, and Asian Studies, for example. Those who are oriented to reading sacred texts thematically (e.g. systematically) may engage with other disciplines that also engage in those themes (e.g. gender studies, critical race studies, political philosophy).

\section{Social Science}

"Social science," refers to scholars who primarily utilize social science methodologies towards increasing the knowledge base in their particular field(s) of study. ${ }^{9}$ Nineteen interviews with social scientists were collected across the participating institutions. Social scientific approaches to religious studies span disciplines including anthropology, sociology, political science, and psychology. While some social science scholars identified relying on quantitative data, no one interviewee relied exclusively on this form of data, and therefore this study's findings cannot represent the research activities and needs of scholars who rely primarily on quantitative data.

The majority of these scholars had affiliations (and cross-affiliations) in academic departments such as religion, anthropology, and sociology, and their methods were also primarily ethnographic in nature, some with overlapping uses of adjacent methods (e.g. oral history, folklore studies) and others also relying on historical or textual analysis (e.g. discourse analysis) but still grounded in social science theories and paradigms. Some scholars from the sample received formal training in other disciplines but are now working in a religious studies department, while others hold doctorates in religious studies but due to their methodological approaches also engage with other disciplines. The majority reported at least some engagement with religious studies, either through attending conferences like the annual American Academy of Religion meeting or publishing in religious studies journals. Area studies, such as South Asian Studies, African American Studies, and other interdisciplinary areas, such as women, gender and feminist studies, were also frequently cited as sites of engagement.

${ }^{9}$ Their work contrasts with arts of ministry scholars, who also rely on social methods, but do so for applied purposes. 


\section{Arts of Ministry}

"Arts of ministry" refers to scholarship that focuses on the spiritual and religious practices of individuals and communities, not only to develop a deeper understanding of those practices but also towards offering support for those practices and those who lead others in those practices. Fourteen scholars aligned with the arts of ministry were selected from the interviews collected by the participating institutions. Arts of ministry scholars are found in departments and schools with professional offerings pertaining to religious practice. Areas of scholarship that align with the arts of ministry include practical theology, homiletics, missiology, pastoral care, religious education, and congregational leadership, among others.

Reflecting the emphasis on practice, research in the arts of ministry tends towards social science methodologies and highly interdisciplinary approaches to the literature and theoretical frameworks utilized. These scholars aim to bring academic theory and method into dialogue with religious teachings and perspectives. They described their research process as involving qualitative or quantitative social science research, and, in addition to the data they gathered themselves (e.g. surveys, interviews), they also rely on quantitative data gathered from other sources (e.g. census), as well as secondary source information primarily from academic books and articles. In addition to experiencing difficulties commonly associated with social science research, such as finding informants and managing field time, they experience additional challenges designing and implementing projects because they often do not receive the same methodological training or experience as social scientists. They engage in a variety of methodologies including, but not limited to, case studies, discourse analysis, oral history, interviewing, surveys, and self-reflection. Similarly, these scholars reported drawing on a variety of theoretical and disciplinary frameworks to guide their research, such as those emanating from education, psychology, ecology, sociology and anthropology, post-colonial studies, public health, and neuroscience, among many others.

\section{Discovering and Accessing Information}

The majority of religious studies scholars reported relying on a combination of primary and secondary source information, with a minority reporting that they rely exclusively on secondary source information. Scholars' sub-disciplinary and methodological approaches determine the kind of primary and/or secondary sources they consult and how readily they can access these sources. Those who rely on interdisciplinary approaches reported challenges conducting primary and/or secondary source research due to lack of specific disciplinary expertise. 
When available, digital discovery and access have greatly improved these scholars' research experiences with relatively few challenges. Most interviewees do not use digitally-driven methodologies for discovering or pulling information from primary or secondary information sources, including their associated records or metadata. Scholars located in standalone seminaries and those conducting research on religions and religious cultures beyond the West experience greater challenges in finding primary and secondary sources.

\section{Primary Sources}

Religious studies scholars work with a wide variety of primary source materials, and the kinds of materials they engage with are reflective of their sub-disciplinary and methodological alignments. With the exception of arts of ministry scholars, most religious studies scholars use primary source materials. Of these scholars, some are using resources that are widely circulated and/or easily accessible digitally (e.g. critical editions, through databases or from institutional special collections or archives that have made their content available online). But for others the primary sources are available through archives or special collections with minimal digital presence.

Reflecting the interdisciplinary nature of religious studies, some scholars who are not trained as historians reported challenges navigating archives in general. As one interviewee in theology explained, "I'm not a historian. And I'm not trained as a historian...doing archival work is something that took me a while to like, figure out how to do it." Similarly, a social scientist remarked, "an archive [is] basically being made with an historian's mind." These comments reflect that some religious studies scholars may benefit from further training for working with archival collections as well as services and structures designed to assist those with little to no experience conducting research in archives.

\section{Digital Affordances}

Many scholars in religious studies reported benefitting from ever-increasing digital access to primary source materials, when available. Those aligned with the humanities, biblical studies, and theology reported working with databases of primary texts and objects (e.g. coins) and digital collections. Scholars generally did not report having difficulty with the functionality of digital collections. Some respondents noted improvements to optical character recognition (OCR) capture to enable searching of digitized documents in a variety of scripts and hoped that this technology will continue to be improved. As one interviewee explained, "The advent of searchable texts is really making an impact. It's very uneven, because optical character recognition is not terribly 
good for the Arabic script. I can't just turn on that kind of function in Adobe, as I can with something in English or French.”

\section{"The advent of searchable texts is really making an impact. It's very uneven, because optical character recognition is not terribly good for the Arabic script. I can't just turn on that kind of function in Adobe, as I can with something in English or French."}

For those in smaller institutions a major barrier is not having institutional subscriptions to primary source collections, which necessitates workarounds. As one interviewee at a small seminary explained, "there [are] Latin texts that we don't have access to... because we're not a big university. So I'll turn to my Christian medievalists, [name of colleague at another institution given]...and he'll look it up for me." The challenges and workarounds reported with accessing primary source collections available by subscription were similar to the challenges associated with secondary source database access (see findings on secondary sources below).

Scholars use a variety of tactics to find information about relevant collections online including consulting specialized aggregates like ArchiveGrid or Archive Finder, searching the open web through general search engines, and targeted searching of specific institutional collections. ${ }^{10}$ While some reported positive experiences visiting physical archives, the majority expressed that when available, digitized collections were a major benefit to their work due to cost and time efficiencies. In lieu of digitized collections, the opportunity to collect the information to analyze off-site is ideal. As discussed in the previous section, scholars did not generally report using new methods to work with digital content beyond text searching.

\footnotetext{
${ }^{10}$ Further information about ArchiveGrid can be found here: https://beta.worldcat.org/archivegrid/. Further information about Archive Finder can be found here: http://archives.chadwyck.com/marketing/index.jsp.
} 


\section{International Archives}

Many interviewees reported working with archival collections physically located beyond the United States. Working with these archives can present unique challenges depending on the locale and type of archives consulted. Similar to findings from Ithaka S+R's report, "Supporting the Changing Research Practices of Historians," interviewees reported that many larger-scale Western European archives were generally wellmaintained and had good digital discovery and access points, necessitating less travel for research. However, levels of maintenance and digital accessibility do vary by country, scale and scope of the archives. ${ }^{11}$ Similarly, one interviewee in this project recounted needing to travel to an archive in Valencia because they had run out of money to digitize their materials, and, upon arrival, having difficulty locating information due to lack of staff knowledge of the antiquated organizational system.

\section{While scholars conducting research in U.S. and Western European archives report at least some reduction in travel due to increased online access to records, many scholars working in archives located beyond the West must still visit collections in person.}

While scholars conducting research in U.S. and Western European archives report at least some reduction in travel due to increased online access to records, many scholars working in archives located beyond the West must still visit collections in person..$^{12}$ These scholars were primarily working on topics pertaining to Islam and religion in Asian countries (including research on Buddhism, Hinduism, and Christianity. ${ }^{13}$ Although archival research is typically associated with humanities scholars, this group of scholars was evenly composed of social scientists. For some of these scholars the challenges of

\footnotetext{
${ }^{11}$ Rutner and Schonfeld, 13-14.

${ }^{12}$ Lara Putnam similarly observes that while the increased digital availability of primary texts is transforming history into more of a "desk discipline" this digitization is uneven (e.g. Western sources, newspaper sources disproportionately represented). See Lara Putnam, "The Transnational and the Text Searchable: Digitized Sources and the Shadows they Cast," The American Historical Review 121, no. 2 (2016): 395.

${ }^{13}$ Archives in other countries and continents were not represented in the sample (e.g. no one interviewee discussed archives in African countries).
} 
working on topics pertaining to religious practice beyond the West can be mediated by working with collections held or made digitally available from Western institutions, but, depending on topic.

Respondents highlighted many different challenges associated with conducting research in countries beyond the West ranging from discovery to access to the physical condition of the materials. Respondents reported that determining what records are in collections and locating them is difficult because collections are often not processed and inventoried systematically and in some cases are deteriorating over time. As one interviewee explained about one experience, "while I'm just kind of pulling stuff off the shelves, I find what I'm looking for bound inside another book that no one knew was there." Even when materials are successfully located, barriers to preservation may still prevent access. As one interviewee explained, "Libraries in India are frequently not in a position to preserve what they've got subject to white ants, termites, fungus, mold, water. Things that you even saw ten years ago, you go back and look at it, and they have been damaged." Another interviewee discussing archives in South Asia also noted, "The quality of preservation is often abysmal and manuscripts that may be recognized as valuable ones have begun to disintegrate. The climate's not conducive to preservation. There are silverfish running all through them, wormholes and things like that.”

Interviewees also often explained how they had to build relationships over years of working with the same archives to ensure access or relying on local contacts. One interviewee noted, "Egypt is always very, very difficult, because the librarians there shut down requests, because they say, "This comes from America. We're not going to work with that." Or Europe. It's different when you are there and you develop relations, but email doesn't help." Another interviewee commented, "I've been doing this long enough now that pretty much anywhere I am that has materials, I can get right to...A lot of my foreign research is dependent on connections and the goodwill of people." Similarly, it can also be difficult to get permission to make copies for future use, necessitating workarounds, such as getting others to make copies and/or making copies without permission or recording as much information in hand-written notes. As one interviewee highlighted, "getting materials out of Tibet or China itself is extraordinarily difficult. Many of those archives are closed, they're not open. So the only way you can get access, if you get access at all, is if you know someone who can maybe locate something and kind of make a copy on the side, quietly." Another interviewee noted, "I might even cheat and take photographs when no one is looking in the name of scholarship [but] mostly, I just work within the limitations that are set for me." It's also important to highlight that nonWestern archives are not universally restrictive, one interviewee explained his experience with Sri Lankan temple archives as follows: "I will ask if I can borrow it for a few hours to go make a copy and they'll always say sure, why not.” 
Scholars also highlighted positive developments such as collaborative projects to digitize and make available materials such as the Endangered Archives Programme at the British Library, and Nepalese-German Manuscript Cataloguing Project (NGMCP) by the Nepalese government and the University of Hamburg. ${ }^{14}$ One interviewee expressed, regarding the Endangered Archives Programme, "I wish in our own way we here at the seminary could support them." Considering that scholars conducting research beyond the West often must develop relationships with archives in those locations, there is opportunity in leveraging these connections and scholars' interest towards developing collaborations with those archives.

\section{Religious Archives}

Religious archives--archives in religious settings including seminaries, theology or divinity schools, church organizations (locally and internationally), and religious societies and orders--represent another source of primary information for some religious studies scholars. ${ }^{15}$ Those who engaged with these kinds of archives highlighted in particular their experiences at archives in church organizations and religious societies and orders. An underlying theme is that these archives are not set up to cater to academic research, which can pose a challenge to scholars. ${ }^{16}$

Interviewees noted that religious archives often rely on volunteers in addition to or in lieu of professional archivists, mainly from the denomination or order the archives represents. While the volunteers are perceived as friendly and helpful to the best of their abilities, some concern was expressed that they lack familiarity with academic research and that can be a barrier to providing research support. Similarly, lack of funding and resources also makes discovery of content challenging: some archives lack

\footnotetext{
${ }^{14}$ Further information about the Endangered Archives Programme can be found here: http://eap.bl.uk/. Further information about the Nepalese-German Manuscript Cataloguing Project (NGMCP) can be found here: https://www.aai.unihamburg.de/en/forschung/ngmcp.

${ }^{15}$ For examples of how Religious Archiving is conceptualized, see "Archivists of Religious Collections Section," Society of American Archivists, accessed October 5, 2016, http://archivists.org/groups/archivists-of-religious-collections-section, and "Religious Archives Special Interest Section," The Association of Canadian Archivists, accessed October 5, 2016, http://archivists.ca/content/religious-archives-special-interest-section.

${ }^{16}$ Academics are just one group that use religious archives, which also includes affiliates of the Church or religious organization the archives serves, and other lay populations, most notably, for genealogical research. For further information about the unique usage patterns and considerations in religious archives, see, for example, Robert C. Ray, "No One Has Ever Seen God," The Use of Religious Archives for Non-Religious Purposes," Journal of Religious and Theological Information 7, no. 3-4 (2009), http://dx.doi.org/10.1080/10477840902783010 and Jonathan Lawler, "Use in Protestant Archives of the United States," Journal of Archival Organization 11, no. 3-4 (2013), 146-174, http://dx.doi.org/10.1080/15332748.2013.939885.
} 
comprehensive findings aids and include backlogs of unprocessed records. Interviewees, however, also emphasized how much they appreciate and value the work of the volunteers.

Another theme that emerged is the perception that religious organizations are more restrictive with providing scholars with access to materials due to the archives' primary mission to serve those organizations. As one interviewee explained, "there's a proprietary sense of things that outsiders shouldn't see." Access to documents may be prevented or the documents may be heavily redacted. Winning trust of those in charge of access is seen as important by building friendly rapport and clearly communicating the motivations for the research. ${ }^{17}$

\section{Secondary Sources}

The widespread digital availability of secondary sources provides religious studies scholars with more opportunities to discover and access this material. There is some variation in how this material is discovered based on whether scholars are aligned with sub-disciplines within religious studies such as the arts of ministry, theology, or biblical studies, and, by extension, whether they seek to engage with literature from other disciplines or are more concerned with how they engage with the literature within their own discipline. Across the sub-disciplines scholars use multiple platforms in tandem to discover content, often as a tactic to combat anxieties that no one platform is comprehensive and to maximize other affordances that vary across platform. Access to secondary content is a challenge for those in some standalone seminaries and for scholars who research religions beyond the West.

\section{Variations in Discovery by Sub-Discipline and Research Method}

While religious studies scholars did not report using specific, systematic methodologies for discovering secondary source information they do display some patterns regarding discovery that mirror their sub-disciplinary alignments and underlying methodological approaches to developing their research projects. For example, some scholars in arts of ministry and theology reported developing projects based on themes and drawing on research from a variety of disciplines, which necessities more open and broad approaches to discovering secondary content across a variety of platforms. For arts of

\footnotetext{
${ }^{17}$ The issue of building appropriate and effective relationships with creators and custodians of information resonates with the experiences of scholars in other disciplines. For example, art historians report challenges navigating relationships with the artists they study. See Roger C. Schonfeld and Matthew P. Long, Supporting the Changing Research Practices of Art Historians (New York: Ithaka S+R, 2014), 13-14.
} 
ministry scholars, secondary research from multiple disciplines, particularly in the social sciences, is used so that it can be applied to issues relevant to the arts of ministry (e.g. using insights from psychology to inform discussion on pastoral counselling). Due to their lack of expertise in these various disciplines, however, some arts of ministry scholars face barriers in determining the best places to find literature and synthesize the content effectively for their purposes. As one respondent explained, "I struggle...with finding the right psychology and sociology materials and even reading and understanding what they're saying." Theology scholars who seek to discover secondary content thematically do so because their research aims are to explore, as one interviewee characterized, "where other discourses put pressure on theology." These scholars report difficulty keeping up with the discourse beyond theology that they seek to engage with and discovering new areas of thinking. By extension, one interviewee suggested that they prefer the method of not keeping up comprehensively, but rather engaging with literature beyond theology in a targeted fashion on a project-by-project basis.

In contrast to theology scholars, biblical studies scholars reported difficulty keeping up with the secondary literature in their own field, which reflects the relative autonomy of biblical studies as a sub-discipline. Their difficulty keeping up with secondary content is also a noteworthy counterpoint to their relative ease managing primary information, as is discussed later in this report. These interviewees characterized the secondary biblical studies literature as vast due to the long history of the field. As one interviewee explained, "Biblical studies is such a massive field, which has been producing secondary literature since the early 1800 s, or the late 1700 , that nobody ever tries to be or can be comprehensive anymore." While some see databases as beneficial for sorting through this vast literature others report finding these tools lacking and report relying on other approaches to cut through the literature, such as informal colleague recommendation, particularly when they perceive comprehensiveness as impossible. As some interviewees highlighted some discomfort with newer database search functionality, this suggests that improved instruction on database searching techniques may be helpful for rectifying these challenges. Considering that Bible scholars generally rely on citation management tools for reading canonical primary texts, synching those tools with discovery tools for secondary literature may have potential as an alternative mechanism for managing the secondary literature in this field.

\section{Discovery as a Multifaceted Endeavor}

While approaches to secondary source discovery vary by sub-discipline, certain characteristics cut across the group as a whole and resonate with larger patterns of secondary source discovery in the humanities and social sciences more widely. Interviewees are largely reliant on and appreciative of the affordances of digital discovery 
tools. They do not generally report using specific, systematic methodologies when searching for content using these tools such as by tracking search results numerically. Automated approaches to discovering content, such as through RSS feeds or customized updates from databases or journals, were rarely reported. In addition to personally searching digital platforms, some interviewees relied on graduate student assistants and librarians to aid in their searching. However, colleague recommendations and following up on footnotes and citations were just as, if not more, likely to be cited as strategies for discovery than librarians. Respondents did not report relying on physical browsing in the library stacks as an initial discovery point although some reflected on the value of open browsing that these organizational systems traditionally afford.

\section{The majority of religious studies scholars concurrently rely on searching databases and platforms beyond their library's offerings such as through WorldCat, Google Scholar, Google Books, Amazon, or general web browser.}

Interviewees reported a mixed approach to secondary source discovery using digital platforms, in part due to delineations between focused searching for specific sources and open or broader searching. The library is not the only stop for most and not even the first stop for some when seeking secondary source information. A typical response reflecting a mixed approach to discovery: "Sometimes it's just on Amazon. I'll be looking up stuff and I'll come across a book that I think would be helpful or sometimes it's just doing searches through the library website. Other times it'll be something that was written about in a journal, a book described in a journal, book review or that kind of thing or mentioned to me by a colleague." The majority of religious studies scholars concurrently rely on searching databases and platforms beyond their library's offerings such as through WorldCat, Google Scholar, Google Books, Amazon, or general web browser. Google Books and Amazon were highlighted for offering digital previews and Amazon was further highlighted for the algorithmic recommendation function based on purchasing habits.

The use of the library catalog in addition to other platforms reflects that while library catalogs are increasingly designed to provide multiple functions concurrently (open and focused discovery, access, citation management), researchers intuitively work from a combination of platforms to maximize the functionality offered by the various platforms in tandem and the affordances of working across different platforms concurrently. In 
this landscape the multi-functional design of library catalogs can be a barrier to effective use: some respondents were not fully aware of or not comfortable with the functionalities that enable researchers to tailor their searching that enable open and focused discovery (e.g. Boolean searching, selecting and de-selecting from menus). As will be discussed in the following section on information management and preservation, some scholars take advantage of cross-functionalities (e.g. saving bibliographic information from the library catalog through citation management software), while others continue to use more idiosyncratic citation management approaches and/or are unaware of these functionalities.

\section{Barriers to Access}

Some scholars from standalone seminaries do not have access through their institutions to particular databases and/or journals. In some cases this is because the scholars engage in interdisciplinary work, which involves seeking out literature in fields beyond what is conceptualized as the purview of their institution's mission. Others highlighted the difficulty of transitioning from larger institutions where they did their $\mathrm{PhDs}$ to the smaller institutions where they work that do not have the same level of access to resources. They utilize workaround strategies such as interlibrary loan, personally reaching out to colleagues (e.g. with better institutional access, or because they know they have the content in their possession, or because the colleague authored the piece), and independently purchasing items.

Beyond the barrier of a scholar's specific institutional location, another major barrier to accessing content is if scholars are conducting research on topics about religious culture beyond Western geographic settings, regardless of the institutional location of the scholar. ${ }^{18}$ As one interviewee working on Chinese-Christian theology explained, "I mainly buy my own books in Beijing. I have my own library in my room. We have decent bookbuying budgets here. Most of the things I need are on my own shelves, or they're difficult to find because they're available in Chinese databases some of which we can access, some of which we can't always." Similarly, an interviewee at another institution whose research focuses on Buddhist theology noted, "the only thing that causes me routine irritation here...is the fact that we do not have complete, individual access to the Chinese databases" and that they also rely on a private library to fill in the gaps and inter-library loan, whenever possible.

\footnotetext{
${ }^{18}$ While this issue appeared to cut across geographic region, it is important to note that only certain locales were represented in the study (South East Asia and the Middle East), whereas other areas were under represented or not represented at all (e.g. Africa, Russia). The findings presented here are not intended to provide the definitive representation of the relative availability of content by region or country, but rather, to highlight how relatively similar challenges to access cut across accessing secondary information emanating from a variety of locales.
} 
Many scholars of Islam also remarked on the explosion of published texts relevant to their research emanating from the geographic areas their research engages with, including edited volumes that contain primary texts and commentaries and secondary works by scholars beyond the West. The majority of interviewees rely on on-the-ground discovery and personally collecting this information. As one interviewee explained, "I have a better library in this room and at home than most American libraries put together. In fact, I would say all American libraries put together for the stuff I work on." Discovery can also be a challenge because of the uneven to non-existent inclusion of this scholarship in Western academic databases and lack of subscription to journals and databases produced beyond the West in U.S. academic libraries.

As the comments above reflect, many scholars reported acquiring texts during research trips, not only because more texts are available abroad but also because they can be acquired there more cheaply. They also acquire edited volumes of primary texts through other collectors, mainly academics working in the same areas, but also, in one case, a website with a collection of texts maintained by "a guy in New Jersey." They recognize that some of this sharing activity may be unauthorized. Scholars also acquire these texts through personal networks, including contacting authors directly.

\section{The barriers to access for scholars conducting research on religious culture beyond the West is connected by those scholars to a sense of marginalization in the academy.}

The barriers to access for scholars conducting research on religious culture beyond the West is connected by those scholars to a sense of marginalization in the academy. One interviewee, for example, highlighted how their library's collection is lacking in contemporary South Asian Hindu content because “there doesn't really seem to be a person who currently has the languages for one to be able to talk to -- I'm sure there's someone who can speak Arabic, but no one who can work in Urdu and Hindi and these other languages to be able to judge what to buy and how." Another interviewee expressed frustration about how the collection at their institution is unbalanced with relatively little information on Islam, "I mean there's six shelves on New Testament criticisms."

Despite this sense of marginalization, the interviewees were ambivalent about their expectations for U.S. academic libraries to provide access to secondary materials produced beyond the West, particularly books. While one informant suggested that U.S. academic libraries should be collecting these kinds of texts, others suggested it would be 
impossible and impractical for most libraries to keep up. While some anecdotal evidence from the study reflected that some scholars do work closely with their institutional libraries to improve collections (e.g. one interviewee in Islamic studies is working with their institutional library to make some of the texts they have personally collected digitally available and another scholar in Islamic studies indicated they would be interested in working with the library more closely to improve the collection), there is potential for much more collaborative work between librarians and scholars to be done in this area. As these scholars do not expect in-house expertise from libraries in their research areas and they spend considerable time building up their own collections, it may be a better strategy for libraries to work more closely with scholars to make those personal collections more widely available.

\section{Information Management}

While the types of information religious studies scholars produce and collect vary by their sub-disciplines, they universally contend with the challenge of managing vast arrays of information that they produce and collect in the process of conducting their research. Biblical studies scholars and some social scientists benefit from software designed to facilitate the analysis phase of their research, and some scholars across the sub-disciplines also rely on software for managing citations and their writing. Regardless of sub-disciplinary alignment, interviewees reported idiosyncratic practices overall for organizing and storing their information. The struggle with digital approaches to citation management and information storage and experience uncertainty around destroying and preserving information following their personal use.

\section{While the types of information religious studies scholars produce and collect vary by their sub-disciplines, they universally contend with the challenge of managing vast arrays of information that they produce and collect in the process of conducting their research.}

\section{Type of Information Collected Mirrors Sub-Discipline}

The types of information that scholars produce and collect over the course of conducting their research varies by sub-discipline. Those who conduct humanistic-inflected research 
(including those aligned with theology or biblical studies) generally characterized themselves as information "consumers" as opposed to "producers." They reported collecting and analyzing primary and secondary source material in both physical and digital forms through annotation, note taking, and draft writing as opposed to creating their own data and/or manipulating pre-existing data sets. The relative lack of engagement with creating or manipulating data reflects that digital research methods, including those associated with the digital humanities, are not widely practiced in religious studies.

In addition to consuming pre-existing information, scholars who engage in social science-oriented research, including arts of ministry scholars and historians who use oral history methods also reported creating data for their research. The data they reported creating was primarily qualitative in nature including: recordings and transcriptions of interviews, documentation of events and activities through field notes, photography or video. Ethnographers in particular are also noteworthy for collecting vast arrays of content created by their informants and communities of study such as literature, newspaper articles, movies, maps, social media exchanges, and other ephemera.

\section{Software for Research and Writing}

Biblical studies scholars and some social scientists rely on software to facilitate the analysis phase of their research by providing platforms to gather, annotate and search information. Some use software to manage information in particular formats, such as photographs, but these practices were not consistent or widespread. While some scholars across the sub-disciplines report relying on more general software to manage citations and their writing, others report barriers to adopting these practices.

For work with canonical primary texts, biblical studies scholars utilize biblical software such as Logos, BibleWorks, and Accordance, which they value for such affordances as quickly searching large amounts of text in lieu of memorizing, annotating texts, and reading texts and linking annotations to the same text across multiple languages. ${ }^{19}$ While the affordances vary between software offerings, interviewees reported prior use as the main reason for working with a particular kind of software. For example, one interviewee noted that they perceive Accordance to be better for their kind of Jewish scholarship but that they continue to use BibleWorks because they have been using it for twenty years. This choice, however, does not necessarily reflect a reticence to learn new software, but also the reality that many have built up their personal annotations and notes in one

\footnotetext{
${ }^{19}$ For further information about Logos, see: https://www.logos.com/; for further information about BibleWorks, see: https://www.logos.com/; for further information about Accordance, see: https://www.accordancebible.com/.
} 
particular system, which ultimately outweighs other benefits that may come from switching.

Some social scientists reported relying on qualitative analysis software such as NVivo for storing and analyzing their data. ${ }^{20}$ While arts of ministry scholars also engage in social science research, they are less likely to rely on the qualitative analysis software. They reported lack of familiarity and training as the primary reasons for not using these kinds of software, but expressed interest in receiving support to learn how to use these tools. These requests were expressed in the context of their general requests for support in social science research methodologies.

Some scholars across the sub-disciplinary spectrum report relying on software for general research and/or writing management, such as Nota Bene, OneNote, EndNote and Zotero. ${ }^{21}$ The ability to work with content in multiple languages is a consideration for some, but it was also noted that the ability to do so is generally improving on various platforms. Due to the learning curve and investment associated with entering information into a particular platform, many report working with the same system over the long term, often beginning during their graduate education. As one interviewee explained regarding their use of Nota Bene "close to 30 years ago, there was no other program that did that. Now other programs have caught up but... a lot of it is just in my Nota Bene files." Some report overcoming prior barriers to learning new software by seeking support from graduate assistants, librarians, and others who are already familiar with the tools. As one interviewee explained, "I have used Zotero and I -- it's actually something my research assistant was trained in through a service offered by the library and he would often do that for me... or some reason I remember my research assistant being told when he was taking this class that EndNote wasn't that great so I've never used EndNote." Similarly, for those who do not use software for managing their information, lack of time to overcome the learning curve with new technology was cited as a concern. They are often unfamiliar with the full capabilities of the software or that software is available that can help them manage their research, which may also be a barrier to exploring and adopting new software.

\footnotetext{
${ }^{20}$ For further information about NVivo, see http://www.qsrinternational.com/nvivo-product.

${ }^{21}$ For further information about Nota Bene, see: https://www.notabene.com/; for further information about OneNote, see: https://www.onenote.com/; for further information about EndNote, see: http://endnote.com/; for further information about Zotero, see: https://www.zotero.org/.
} 


\section{Idiosyncratic Approaches to Organization and Storage}

Scholars generally develop idiosyncratic approaches to organizing and storing the information associated with their research. Their organizational systems, including conventions for naming and grouping information, are highly personal and developed over the course of their careers. These scholars rely on common tools and materials to create their systems, such as series of Microsoft Word documents placed in folders, and physical documents in folders in boxes and filing cabinets, which they often recognize are not ideal for quickly searching for information across their entire collection. Many create organizational systems to mirror and facilitate their writing processes. Others admit to not having much of a system at all and being disorganized. Those who use research analysis or management software often still have other caches of information organized and stored elsewhere.

Interviewees reported storing information in a variety of places, both physically in institutional and home offices, and digitally on personal computers, external hard drives, and through cloud storage through their institutions or commercial entities (e.g. Dropbox, Google Drive). In some cases this information may be duplicated in different storage mechanisms, and in others the information is scattered across the different storage mechanisms. As a result, some struggle with remembering where their information is stored. As one interviewee explained, "I'm getting these big, multimegabyte text files now. I have some of them on Google Books [sic] and some of them on a hard drive and some of them on Dropbox, but maybe I should just do the subscription for the larger memory on Dropbox so I could have it all in one place so I don't keep wondering where I've stashed these things." In some cases this scattering practice reflects that no one cloud-based storage system provides sufficient space for free.

\section{Seeking Support for Long Term Preservation}

Beyond managing and storing the information associated with their research for their more immediate use, scholars must also contend with how their information is preserved over time, possibly with a view towards making that information available to others. Their plans and attitudes towards preserving their research information in the long term was mixed, with some not perceiving their information as valuable beyond their own use, others being required to destroy at least some of the information by their institutional review boards, and other still interested in exploring long term solutions but unsure of how to proceed. They find the expectations for how they should collect and maintain information in the long term unclear, including whether and how their information should be donated to memory institutions. As one interviewee noted, "It's easier to collect the material than it is to actually pull it together and to, to make arrangements to 
donate it and I need to do that." In this confused landscape many expressed a need for support for navigating their information management in the long term, both in terms of their own collection and storage and towards making arrangements for future use by other researchers.

For some scholars, preserving information in the long term is not possible or desirable. Some interviewees noted that they wanted to destroy their information but were unsure of when it is appropriate to do so. Conversely, those who conduct research on human subjects may be required to destroy or redact components of the information they collected or in particular formats. For example, redacted transcripts may be acceptable but the original audio recordings must be destroyed. While being cognizant of the need to destroy the information, some expressed confusion over what needed to be destroyed and suspected that they had not properly complied. Some also expressed frustration with requirements to destroy information because it could be useful to other researchers.

Prior to destroying the information associated with their research or donating some or all of it to an institution, scholars reported typically keeping their personal information collections for long periods of time, sometimes spanning multi-decade careers. As mentioned above, the choice to hold onto this information isn't necessarily intentional: scholars often chose to hold onto information out of habit or uncertainty about whether or not they should dispose of it. Regardless of intentionality, maintaining content over the long term in their personal collections is an issue for scholars, particularly as they contend with evolving formats and deteriorating content, which they don't have the resources or capacity to migrate. For many, the information they collected earlier in their career is degraded or in formats that are difficult to access or even obsolete. As one interviewee explains, "For a person like me who actually wants to be able to go back and keep all the electronic files just like I would in a file cabinet and be able to pull them out, well, that's not so simple. That really frustrates me." Another interviewee suggests, "[we need to] find ways to store our data more cheaply and more easily - where the formats just update themselves or things just happen automatically." Another barrier to long term preservation and wider use is that scholars do not have preservation in mind when collecting and managing the data at the outset, which means it may have been stored in ways that destroys the content over time.

While it was more typical for interviewees to report not having considered or made concrete plans for donating their personal information collections to institutions for future use by others, those who did highlighted the role of proactive librarians and archivists in making these decisions. For example, one interviewee noted: "I've actually been approached by several librarians who are interested in archiving some of the data from the first interview set that I have. ...So I'm thinking about how to do that and in 
what ways I would do that." Similarly, another interviewee highlighted: "I've been thinking about offering the material to a library collection. I've been talking to, for instance, the library [at their home institution] as well, but also I was approached by a reference librarian at [another academic library geographically located near their research community]."

It is also important to highlight that interviewees did not generally report concerns with the availability or long term preservation of their published content. This is particularly noteworthy in the context of interviewees' reported preference for Academia.edu, as discussed in the following section. The issues of Academia.edu's business model (and the implications for how their activities or the security of when their information will be preserved) was not an issue to respondents.

\section{Audience, Output and Credit}

While many scholars perceive that their work on religion has wider value beyond academia, their primary focus remains on traditional scholarly outputs due to the expectations associated with their professional development as academics. Overall awareness and engagement with open access is low but the perceived importance of more freely sharing work as enabled by social media platforms such as Academia.edu is high. Those who conceptualize their work at the intersection of theory and faith-based practice contend with achieving balance between academic and non-academic publishing activities. Engaging with society-at-large is not prioritized by most scholars despite their perceptions that their work and religious studies as field is of wider value.

\section{Primary Emphasis on Scholarly Outputs}

The majority of interviewees reported a primary focus on producing peer-reviewed journal articles, chapters in edited monographs, and single-authored scholarly monographs. They highlighted that scholarly outputs remain the primary end goal due to the expectations for tenure and promotion. Beyond peer-reviewed published outputs, interviewees also reported participating in a variety of other typical scholarly venues to communicate their work. These venues include invited talks, conference presentations, and contributing encyclopedia or dictionary entries. Alternative scholarly outputs, such as those associated with the digital humanities and quantitative data, or with experimental academic publishing venues (e.g. Syndicate Theology), were noted by a minority of the interviewees. Similarly, collaborative projects and co-authorship on research outputs were not widely reported. 
The key concerns scholars noted about publishing their research were connected to their professional advancement. Typical concerns include producing an acceptable number of outputs and publishing in appropriate venues based on reputation and audience. In some cases interviewees reported that their sub-disciplinary areas (e.g. history) privilege full-length, single-author monographs, particularly towards granting tenure and promotion. As one interviewee explained, "I don't get credit with a co-authored book, when I would love to do collaborative work like that." Similarly, creating critical editions and translations was also commonly mentioned as an important endeavor in religious studies alongside frustration that these projects are less valued towards tenure and promotion than writing articles or books. Many highlighted the freedom that comes with achieving tenure to publish less and focus on different kinds of outputs. Inability to frame alternative outputs, such as those associated with the digital humanities, in the context of tenure and promotion is an ongoing barrier to pursuing those kinds of work.

The venue of publication varied by sub-discipline and institutional home of the respondent. Those aligned with religious studies in conjunction with the more general humanities and social sciences seek to publish with presses and publications geared toward academic audiences that specialize in their sub-disciplinary areas as the tenor of the project dictates. Many receive their training in disciplines other than religious studies and continue to publish at least in part in those other areas as opposed to exclusively publishing in religious studies. In contrast, some arts of ministry prefer to seek out religious or theological publishers. Some interviewees expressed anxiety over the state of the academic publishing industry, highlighting difficulties getting their work published due to increased expectations around marketability even in university presses.

A small group of interviewees reported publishing their academic work in venues beyond the West and they perceived their practices as atypical. Motivations for publishing scholarly work in these venues despite the associated barriers include fostering collaboration with scholars beyond the West and the opportunity to disseminate research to audiences who will be interested in the findings. They noted ongoing barriers to publishing scholarly work beyond Western academia such as: lack of knowledge or resources for translating work, difficulties navigating the terrain of publishing beyond the West and lack of recognition at their institution for such endeavors. 


\section{Ambivalence towards Open Access}

The majority of interviewees, regardless of their sub-disciplinary or institutional affiliation, reported minimal awareness of or engagement with open access frameworks for disseminating their research in either green or gold varieties. ${ }^{22}$ Their perceptions of and the level of prioritization they assign open access publishing is consistent with scholars in the humanities and social sciences more widely. ${ }^{23}$ Many displayed confusion over the meaning of terms such as "open source" versus "open access."

The majority of interviewees did not report regularly publishing in open access journals, nor did they report paying for their articles to be open access in proprietary journals or that their institutions or funders required them to do so. When prompted as to why they had not published with open access journals, interviewees primarily expressed that their priority was to publish in appropriate venues for professional advancement and that in their sub-disciplinary areas these venues were not open access. Others expressed general distrust or uncertainty of open access as a model that can publish work appropriate for academic standards generally and, by extension, that it would not be productive towards their tenure and promotion in particular. Similarly, the minority of respondents who had published with fully open access journals did not generally seek out these venues intentionally, but rather, had sought out journals for reasons typically associated with academic publishing, such as the publication is peer reviewed and considered appropriate for their subject matter.

Several respondents expressed that they preferred proprietary publishing models because they felt that authors and publishers should financially benefit from publishing academic work. In contrast, those who had not previously published in open access journals generally highlighted that they would be amenable to publishing under such models as long as they adhered to standards that were complementary to academic publishing protocols and could be recognized in tenure and promotion processes accordingly. As one interviewee explained, "For me, where I am in the early part of my career, I'd be open to open source...so long as they're peer reviewed.” Similarly, another

22 "Gold" open access generally refers to open access journals, regardless of business model whereas "green" generally refers to open access repositories. For further information, see Peter Suber, Open Access (Cambridge: MIT Press, 2012), 175 .

${ }^{23}$ See, for example, Martin Paul Eve, Open Access and the Humanities: Contexts Controversies and the Future (Cambridge: Cambridge University Press, 2014), 30-34; Stephen Pinfield, "Making Open Access Work: The 'State-of-theArt' in Providing Open Access to Scholarly Literature," Online Information Review 39, no. 5: 612-614. 
interviewee highlighted, "I think that's a great thing. It's just in terms of what I have been working on th[ere] hasn't [been] the right journal."

Interviewees also reported minimal engagement with open access repositories. ${ }^{24} \mathrm{~A}$ minority of interviewees at institutions with such repositories reported depositing their work. In the process of depositing, "leg work" from librarians is appreciated and fosters participation. As one interviewee explained, "I just got an email yesterday from the person at the library in charge of that who found out for me all the journals in which I have published, and gave me a list of 'here's what we can put in the repository'...And it's up to me to go track down the terms of all these agreements. I'll probably never get around to it [on my own], they want to build that repository so they are doing the leg work for me.” A small group reported putting copies of their published work on personal websites.

Respondents were more likely to report engagement with other forms of open access dissemination beyond journal and repository models, primarily in association with producing secondary outputs other than their primarily academic dissemination activities. These forms include writing for blogs, departmental websites, or organizational online newsletters. Awareness of or interest in open models for publishing monographs was virtually non-existent among respondents with the exception of one interviewee engaged with digital humanities research.

When asked about open access, many respondents noted that they utilize Academia.edu, both by posting their own work, and to discover and acquire the work of others. ${ }^{25}$ These respondents were generally unsure as to whether Academia.edu constitutes "open access," or is adjacent to open access, which suggests that they are unaware of the nuances of how open access is defined and that these definitions (and their associated business models) are not a primary motivator for participating in open dissemination models, but rather, they are interested in unfettered discovery and access to information. As discussed in the previous section, they also did not report awareness or concerns around the long-term preservation capabilities of Academia.edu. Their ease with

\footnotetext{
${ }^{24}$ The lack of participation in institutional open access repositories found here is reflective of wider trends traversing disciplines and institutions. For example, as of July 2016 the University of California's state-created repository is only being used by $25 \%$ of professors even with using a computer system that automatically emails professors with links for putting articles into the repository. See Paul Baken, "The U. of California's Open-Access Promise Hits a Snag: The Faculty," The Chronicle of Higher Education, July 7 2016, http://www.chronicle.com/article/The-U-of-California-s/237044.

${ }^{25}$ Other academic social network platforms were not generally mentioned by respondents, which may reflect disciplinary preferences.
} 
Academia.edu also reflects how the platform enables an activity that academics already practice: relying on their networks to discover and acquire research sources.

When engaging with Academia.edu, respondents also expressed mixed attitudes as to their knowledge of and compliance with copyright. While some expressed awareness of compliance of copyright issues when using the service, (e.g. "anything that I publish I'll put up on my Academia site unless the journal or book tells me not to"), others expressed uncertainty and that they and their colleagues post regardless of that uncertainty. For example, one respondent noted: "I'm a little bit hazy on the legality of this - but most people that I know, everything that gets published is up on their Academia page pretty quickly." Similarly, another interviewee noted, "I don't know if it's completely openaccess or available to registered users. I haven't done that. Some of my publications have ended up [on Academia.edu] because other people have put them there. That's okay with me, but it's probably not entirely kosher."

\section{Challenges Engaging with Audiences beyond Academia}

Some scholars noted that they also share their research with audiences beyond academia because their work is relevant to a wider public. Those who do so typically position these efforts as secondary to or in conflict with their scholarly publishing practices.

Interviewees also reported different experiences and challenges with disseminating their research beyond academia depending on which publics, and by extension, which venues, they seek to engage with.

Religious studies scholars who disseminate their work in the context of public scholarship report producing such outputs as articles in mainstream media publications, posts on blogs, participation in podcasts, as well as workshops and public talks. One significant form of output in this area is represented by biblical studies scholars, who produce and disseminate insight into biblical texts for audiences beyond academia, for example, through venues like the Society of Biblical Literature's Bible Odyssey. Public scholarship is also an opportunity for some scholars to engage beyond Western contexts, including with the communities that they research. As one interviewee noted, "Most of my scholarly works have been published in English. And for the Korean, I'll write like a blog and not necessarily scholarly work. More like, you know, public engagement thing." Public engagement also represents an opportunity to challenge negative perceptions of particular faith practices in the mainstream.

Barriers to pursuing public scholarship generally include lack of time and reward for non-academic publishing within academia, difficulties seeking and translating academic work for legibility beyond its originally intended audiences, and challenges navigating 
new digital media technologies. The barriers that religious studies scholars experience are consistent with scholars in other disciplines and various career stages. ${ }^{26} \mathrm{How}$ religious studies scholars manage intersections between their personal and public media identities did not yield sufficient findings, which suggests grounds for further study. ${ }^{27}$ One interviewee in this study highlighted the challenges with public engagement when communities are critical of the concept of Western academic approaches to studying their religion, citing their own area of research on Hinduism. They noted that "now books are banned in India that are written by American scholars.”28

Beyond engaging with the general public, some scholars also displayed unique publishing practices because their research falls at the intersection of theory and faithbased practice, which necessitates engaging with religious audiences beyond academia. As one interviewee explained, "there's a balance where I want to contribute to the wider academic world but I'm also committed to the life of the church.” Typical forms of engagement including writing for blogs, magazines, journals and news outlets of organizations associated with their institutions or other organizations serving faith communities, many of which are open access. Some of these scholars report producing trade publications and other monographs oriented toward educating lay audiences, and in some cases, these publications may function as the primary output in lieu of scholarly publications (when allowable due to the culture of the institution or if the scholar is not focused on promotion). They experience challenges seeking appropriate venues for their work because their research is perceived as not academic enough for university presses but too academic for religious presses. Some report achieving balance by focusing on "denominational" outputs later in their scholarly careers when they are less focused on tenure and promotion. As some denominational publishing houses have academic branches while others do not, this is also a major consideration when determining an appropriate venue for work. Some scholars in this group also report relying on selfpublishing.

\footnotetext{
${ }^{26}$ For further information see Jessie Daniels and Polly Thistletwaite, Being a Scholar in the Digital Era (Bristol: Policy Press, 2016), 100-107.

${ }^{27}$ For example, some scholars may experience larger volumes of requests to comment on their research in public based on their area of study and trends in public discourse. Scholars also have varying experiences when participating in the public sphere due to their positionality due to gender, race or religion.

${ }^{28}$ This observation is similar to Wendy Doniger's in the Chronicle of Higher Education, which also highlights the particular challenges facing Western scholars of Hinduism due to the punitive actions of particular Hindu groups that challenge the validity of Westerners and non-Hindus as scholars of Hinduism. See Wendy Doniger, "The Repression of Religious Studies," The Chronicle of Higher Education, 20 April 2016. http://www.chronicle.com/article/The-Repression-ofReligious/236166?key=dRRz1Bx8HUWt6A96tLgJrHJmdVxUWx3K9pDORyC9do5RU16ZW9hc2xDaEo0RExmTDdkLVZEMIICWWpXRUNCQ0o2bFBSMWNsSGpV.
} 


\section{Digital Humanities}

Reflecting trends in the humanities, digital scholarship and research priorities in higher education, how and the extent to which the digital humanities is emerging as an area of research activity for religious studies scholars is an important question. In recognition that "digital humanities" is a broad term that may relate to various aspects of the research lifecycle in which technology and humanities intersect, the findings on the digital humanities have been separated out from the other sections of this report. ${ }^{29}$ As the project did not specifically recruit interviewees on the basis of their level of engagement with the digital humanities, the findings capture activity trends and perceptions of the digital humanities among religious studies scholars more widely.

Five scholars in the sample reported engaging in projects that utilize digital research methods and all described these projects in the context of the "digital humanities." The projects varied in their content and approach, such as using GIS to map shrines to pulling APIs from online catalogs to develop a distant reading tool. ${ }^{\circ}$ The projects were primarily experimental, overlapped with teaching aims, and were developed in addition to, as opposed to in lieu of, other scholarly outputs. As a corollary, it was highlighted that it is challenging to articulate the value of this work during the tenure and promotion process.

The projects were largely collaborative in nature and engaged a variety of stakeholders including other scholars, librarians, institutional staff with technological expertise, and in one case, a software company. One interviewee observed that collaborative research methods are not traditionally practiced in religious studies as they are in other fields. As another interviewee explained: "I think that the biggest learning curve for us was our digital humanities project because it's not the way we're trained. We're trained to work in a silo, to have our own independent work...and now once you enter the digital humanities, we didn't know how to code. We didn't know how to build a database."

Interviewees highlighted that collaboration is essential for the success of these projects because they rely on disparate skill sets and knowledge, particularly of the technological variety. For example, one interviewee noted that the success of their project hinged on

\footnotetext{
${ }^{29}$ For further discussion how the digital humanities functions as an over-arching concept, see Brett Bobley's definition in Michael Gavin and Kathleen Marie Smith, "An Interview with Brett Bobley," Debates in the Digital Humanities, edited by Matthew K. Gold, University of Minnesota Press, 2012, 61-66

${ }^{30}$ Distant reading is a method of literary analysis that relies on collecting and analyzing large quantities of data. For further information see Franco Moretti, Distant Reading, London: Verso Books, 2013.
} 
finding the "right people" to work with while overcoming the steep curving of learning to work with the technology and the digital methods. Another interviewee who

unsuccessfully applied for a grant to do a digital humanities project also suggested that it was this lack of technological knowledge combined with the inability to find support which led to difficulties in their application process. Even when good collaborators are found, however, there is still the barrier of coordination: one interviewee noted the need for project management support.

\section{Conclusion}

Broader conclusions that cut across religious studies scholars' research experiences emerge from the findings presented above on discovering and accessing information, information management, audience, output and credit. Religious studies scholars develop significant information collections over their course of their careers and these activities are generally unmediated by their institutions or informational professionals. They benefit from the affordances of digital technologies but the majority do not engage with emerging digitally-enabled research methods. While religious studies scholars rely on resources provided by their institutional libraries the library is not central to their research processes.

\section{Religious studies scholars develop significant information collections over their course of their careers and these activities are generally unmediated by their institutions or informational professionals.}

\section{The Scholar as Collector}

In the process of conducting research and developing final outputs, religious studies scholars amass collections of material produced by others and themselves, in both analog and digital formats. The variety of formats reflects that scholars' collections are developed over the course of their careers. The content ranges from primary materials reproduced while visiting archives and special collections, or collected while conducting field work, to secondary content downloaded through institutional access or through purchase. They also produce and manage information created in the process of analyzing information and the content they produce towards publishing their final outputs. The 
information may be stored in analog or digital formats and scholars often have collections of different materials in both formats. Their organizational approaches may be self-designed or under-designed. They struggle with the best ways to store and organize information, including when it is appropriate to discard materials.

Religious studies scholars' collections emerge in part due to necessity, in part due to preference and in part due to inertia. ${ }^{31}$ For example, similar to findings from Ithaka $\mathrm{S}+\mathrm{R}$ 's history project, scholars who still rely on visiting physical archives now prefer to use those visits to collect information (e.g. by photographing or scanning documents), however, these missions are essential for those researching cultures in which the content can only be found in institutions beyond the West. Similarly, while many scholars generally continue to purchase at least some of their books, the need to do so is especially pressing for those who must consult books published beyond the West, often acquired while in the field.

Although generally not the aims of collecting, some scholars share their collected content (primarily secondary) with others as part of the larger culture of networking and informal information sharing among academics. Some are aware that the primary information collected over the course of their research may be of wider use, particularly when it pertains to information not widely available in Western institutions. Information professionals provide a crucial role in helping scholars identify and donate primary materials.

\section{Digital Research is both Ubiquitous and Marginal}

While religious studies is often highlighted as part of the origin of digital humanities and biblical studies scholars rely heavily on digital software to do their research, these connections have not translated into widespread adoption of digital methods within the field. ${ }^{2}$ Findings from this study were consistent with this trend as only a small minority of scholars reported engaging with, or even interest in or awareness of, emerging digital research methods, including those associated with the digital humanities. The relative

\footnotetext{
${ }^{31}$ The preference for amassing personal collections may cut across disciplines. See, for example, Lucy Campbell, "The Information Seeking Habits of Architecture Faculty," College \& Research Libraries (2016): http://crl.acrl.org/content/early/2016/07/27/crl16-930.full.pdf, in which a survey of architecture faculty recently ranked personal books highly among internet resources, and conversations with peers as important to their research process.

${ }^{32}$ Caroline T. Schroeder, "The Digital Humanities as Cultural Capital: Implications for Biblical and Religious Studies," The Journal of Religion, Media and Digital Culture 5, no. 1 (2016): 23-24.
} 
lack of engagement with these methods is consistent with findings from Ithaka S+R's previous studies on scholars in history and art history. 33

In contrast to religious studies scholars' still rarefied engagement with new digital research methods is the ubiquitous use of digital information and tools to facilitate research processes more widely. Similar to findings from Ithaka S+R's history project, digital discovery approaches, often achieved through deceptively simple text box searching, are pervasive but not generally discussed, reflected upon, or employed systematically. This taken-for-granted perspective on digitally-enabled research processes is consistent with Lara Putnam's characterization of historians' reliance on text box searching: "Such practices fall into the realm of invisible method, the black box where by consensus we leave so much of our discipline's heavy lifting." The invisibility of the common elements of digital research such as text box searching suggests the need for greater attention to and awareness of research methods facilitated by digital infrastructures in religious studies and the humanities more widely.

In addition to being largely taken for granted, it is also important to note that many religious studies scholars experience discomfort and difficulty with digital technologies as well as lack of awareness of those technologies' full capabilities. Some do seek out support from their libraries and other sources of technological support at their institutions but, when available, they are more likely to rely on graduate student assistants to take on these tasks or teach them how to use new technologies. Those who do have awareness of and comfort with digital tools that help the research process do encourage their usage in their capacity of educating graduate students, however, the lack of interest in and update of more systematic and explicit digital research methods among scholars interviews, leads to questions about how this methodological training can be shared with students.

\section{The Role of the Library in a Crowded Information Landscape}

This study is in a unique position to gauge scholars' relationship to their institutional libraries because of the project's U.S.-wide and non-library specific scope. The semistructured interview guide used for this study deliberately did not ask explicit questions about how interviewees perceive or engage with their institution's libraries to elicit the fullest understanding of their research activities and needs. The participating research

\footnotetext{
${ }^{33}$ Roger C. Schonfeld and Jenifer Rutner, Supporting the Changing Research Practices of Historians (New York: Ithaka S+R, 2012), 29-30; Roger C. Schonfeld and Matthew P. Long, Supporting the Changing Research Practices of Art Historians (New York: Ithaka S+R, 2014), 14-16.
} 
teams who collected the interviews from scholars at their own institutions were also instructed to recruit scholars regardless of prior relationship to their institution's libraries to gain as wide a perspective as possible.

Apart from a distinct minority of fans, interviewees did not generally place their institutional libraries at the center of their research activities or needs. Those in the minority typically had developed relationships with particular librarians who had helped them with specific tools or projects. In contrast, most described their use of their institutional libraries in the context of discovery and access of secondary information and had relatively few complaints about these services in relation to other elements of their research process and lifecycle. This project did not explore perceptions or experiences with using libraries towards teaching, however, findings from Ithaka S+R's 2015 U.S. Faculty Survey and some comments by interviewees in this study suggest the possibility that religious studies scholars, like scholars in many disciplines, increasingly see the role of the library in the context of supporting their students and their teaching as opposed to their own research, which warrants further exploration. ${ }^{34}$

While religious studies scholars continue to rely on their institutional libraries, particularly for access to secondary materials, their use of the library is placed among many other strategies for finding and accessing information. The library website or specific databases are consulted, however, these resources are typically consulted in tandem with other entry points such as Google Scholar, Google Books, Academia.edu, Amazon, general web searching, and reaching out directly to peers. ${ }^{35}$ Searching multiple platforms regardless of institutional location is essential for maximizing the possibility for discovery and access. The physical library is not approached as a site for information discovery, and peers are just as likely if not more likely to be consulted for research questions because of their deep subject-specific knowledge and/or because they are located in institutions with different levels of access to materials. ${ }^{6}$ Scholars are also as likely to consult with graduate students or design personal systems for organizing materials without outside input despite minimal knowledge of best practices for information preservation. Scholars generally expect that they will rely on a variety of

\footnotetext{
${ }^{34}$ Wolff, Rod and Schonfeld, 68.

${ }^{35}$ By highlighting how religious studies scholars typically consult a variety of discovery platforms in tandem, this finding extends insight from Ithaka S+R's 2015 Faculty Survey, which found that of four possible starting points for their research, faculty are just as likely to begin with a general purpose search engine as they are with a specific electronic research resource/database and almost as likely to begin with their online library website or catalog. See Wolff, Rod and Schonfeld, 12.

${ }^{36}$ This finding is consistent with the Ithaka S+R's 2015 Faculty Survey, which finds that that physical library continues decline as the site for the possible starting point for research. See Wolff, Rod and Schonfeld, 12.
} 
institutions for their primary information due to their specialized research pursuits and they personally collect a variety of primary and secondary materials due to both necessity and preference over the course of their careers.

Fostering a larger role in religious studies scholars' research processes beyond resource procurement and some facilitation of discovery requires very strong initiative from librarians and the institutional culture more widely. The minority of religious studies scholars who were aware of and exploring possibilities for donating their personal collections to libraries and special collections were doing so because those institutions had reached out to them directly. Religious studies scholars continue to have minimal awareness of open access and their publishing motivations remain governed by the benchmarks of tenure and promotion, in which open access is not a priority. ${ }^{37}$

\section{Recommendations}

\section{Discovering and Accessing Information}

- Support endangered archives. Primary source materials are at risk in archives of those religious institutions that have a lack of funding or staff expertise. In other cases, important archives are held in countries where economics pose a challenge to preservation or access. Collaborative efforts between information and museum professionals, scholars, scholarly societies, and foundations could help to support conservation and/or disseminate fragile collections virtually.

- Improve collections for areas of religion study and geographic regions. To improve these collections, which support important and growing areas of study in many of this study's participating institutions, cooperative approaches are needed. Some libraries may wish to explore collaborations that share the capacity of subject specialists with the necessary language and subject expertise to develop these collections. This would permit coordinated if not actually shared collections to develop efficiently. In the near term, institutions might hire visiting consultants to help them build such collections.

- Train researchers on digital tools. Digital tools are emerging far faster than researchers are adapting their practices to take advantage of them. Libraries should provide more regular and proactive outreach to the researchers they support to raise awareness of new digital research tools and gain the needed skills and adapt their workflows to use them effectively.

\footnotetext{
${ }^{37}$ Emily Drabinksi's account of working on the journal Radical Teacher, which resulted in flipping the journal to an open access model, provides a compelling example of how librarians can deeply engage with scholars in the area of research dissemination. See Emily Drabinski, "Flipping to Open Access for Survival: A Librarian's Critical Role in Transforming a Journal," College and Research Libraries News 77, no.10 (2016), 488-491. http://crln.acrl.org/content/77/10/488.long.
} 
- Provide personalized discovery tools. One key tool that is not available through discovery platforms is a tool that provides recommendations based on peer reading habits. Interviewees currently rely on Amazon's recommendations feature to approximate this kind of function. Ideally, when vendors design these tools they should pair these improved discovery features with easy access to the texts through digital previews or full text integration.

\section{Information Management}

- Train graduate students on information management. Information management habits, such as citation management, are often formed during graduate study. Many faculty rely on their graduate students to introduce them to approaches to information management. Training and ongoing support in technologies and techniques are needed.

- Improve usability of citation management software. Citation management tools continue to evolve but the majority of scholars do not experience the full benefits of these improvements by virtue of their design. Lack of migration pathways between citation management software systems is a barrier to scholars adopting newer technologies over time. The difficulties learning new technologies prevent scholars from exploring and adapting available tools for their information management needs.

- Develop centralized policies, mechanisms and guidance for storing and preserving information collected and produced by scholars throughout their research lifecycle. Who has responsibility for scholars' information management, storage and preservation while the information is still in the scholars' custody is unclear. Taking a stronger role in these areas is a potential growth opportunity for libraries. Provide adequate and user-friendly digital storage solutions to remediate scholars' current prevalence of de-centralized storage and preservation approaches and develop programs to help manage their information.

\section{Audience, Output and Credit}

- Advocate for and create rewards that encourage more widespread adoption of innovative approaches to research dissemination. Lack of tangible recognition and reward, most notably through the tenure and promotion and research funding processes, is a major barrier to scholars producing research outputs beyond peerreviewed scholarly articles and books published in primarily via commercial, university press, society and other traditional publishing venues.

- Offer services that promote scholarly engagement with the public. Scholars do not receive systematic training in how to translate their research into wider public outputs or how to navigate the complicated terrain of digital media. Scholarly societies 
represent a potential venue to advocate and provide value-added services around public scholarship for their members..$^{8}$

- Improve institutional repositories' aims and functions. Scholars' investment in institutional repository programs will remain low in the absence of stronger requirements and rewards for participating and/or improved functionality for the purposes of research activities. Develop interoperability and improve discovery mechanisms between institutional repositories and social media platforms for sharing scholarly work.

\section{Overall}

- Develop programs and training to support scholars in their capacity as collectors. Create guidelines and policies for scholars and information professionals to ethically foster relationships with records creators and custodians of collections in religious archives and archives beyond Western institutions. Improve and create platforms and programs for scholars to make the content they collect more widely available to others and earlier in their careers.

- Create training programs and projects that prepare researchers to work collaboratively. Developing collaborative skills is traditionally perceived as outside the purview of scholarly training. Collaboration is crucial because digitally innovative research projects rely on leveraging a variety of expertise and knowledge.

- Conduct further research into the research support needs of non-tenured scholars including independent scholars and adjuncts. Scholars are increasingly conducting research while not being a part of the tenure system. Understanding their unique research activities and needs is crucial to designing research support services to adequately support them.

\footnotetext{
${ }^{38}$ Jessie Daniels and Polly Thistletwaite's recommendations about the wider need for scholars to receive training in digital media and the role that scholarly societies can play in this training was informative towards our finding here, see Daniels and Thistlethwaite, 105-106.
} 


\section{Appendices}

\section{Appendix 1: Participating Research Teams}

1. American Theological Library Association: Gillian Harrison Cain, Margot Lyon, John Meeks, Veronica Simms, Maria Stanton

2. Asbury Seminary: Wesley Custer, Thad Horner, Paul Allen Tippey

3. Baylor University: John G. Bales, John Robinson

4. Brigham Young University: Trevan Hatch, Ryan Lee, Gerrit van Dyk

5. Columbia University Libraries: Nisa Bakkalbasi, Matthew Baker, Beth Bidlack

6. Concordia Theological Seminary: Robert Roethemeyer, Kay Roethemeyer

7. Emory University: Richard Adams, Rebekah Bedard, Sarah Bogue

8. Harvard University: Gloria Korsman, Reed Lowrie

9. Jewish Theological Seminary of America: Ina Cohen, Naomi Steinberger

10.Luther Seminary: Trisha Burr, Andrew Keck

11. Naropa University: Nicholas Weiss

12. Princeton Theological Seminary: Virginia Dearborn, Jenifer Gundry, Kate Skrebutenas

13. Rice University: Elka Tenner, Amanda Thomas

14. Temple University: Justin Hill, Rebecca Lloyd, Fred Rowland, Nancy Turner

15. Tufts University: Chris Strauber

16. University of North Carolina at Chapel Hill: Kathryn Flynn, Jacqueline Solis, Steve Squires, 17. University of Notre Dame: Hye-jin Juhn, Jean McManus

18. Vanderbilt University: Chris Benda, Bill Hook, Michael Kohut, Ramona Romero

19. Yale University: Suzanne Estelle-Homer, Graziano Krätli, Christine Pesch Richardson 


\section{Appendix 2: Participating Institutions: Demographic Characteristics}

The table below is designed to briefly capture some key demographic information about the participating institutions. See Appendix 4 and the participating institutions' websites for more detailed information about how religious studies is defined and administered across the participating institutions.

Notes about the table:

- At Brigham Young University, religious studies is not offered through a single department or program but is represented through courses offered across the Faculty of Arts.

- The Burke Library at Union Theological Seminary is owned and managed by Columbia University Libraries and serves many different constituencies, including Union Theological Seminary, Columbia University, Barnard College, and New York Theological Seminary. Union Theological Seminary is an independent seminary. Barnard College is an independent women's liberal arts college which is affiliated with Columbia.

- At Jewish Theological Seminary of America, undergraduate students pursue a JTS major in fields such as Jewish Thought, Midrash, or Jewish Gender and Women's Studies, while completing a second major through the liberal arts and science offerings at Columbia University and/or Barnard College. Jewish studies at the graduate level is offered through JTS's Gershon Kekst Graduate School. 


\begin{tabular}{|c|c|c|c|c|c|}
\hline Name & $\begin{array}{l}\text { Standalone } \\
\text { seminary }\end{array}$ & $\begin{array}{l}\text { Seminary, theology, or divinity } \\
\text { program affiliated with a } \\
\text { university }\end{array}$ & $\begin{array}{l}\text { Religious studies } \\
\text { offered through a faculty } \\
\text { of arts and sciences }\end{array}$ & Carnegie Class (Basic) & $\begin{array}{l}\text { Public/Private } \\
\text { Status }\end{array}$ \\
\hline Asbury Seminary & Yes & No & No & $\begin{array}{l}\text { Special Focus Four-Year: } \\
\text { Faith-Related Institutions }\end{array}$ & Private not-for-profit \\
\hline Baylor University & No & George W. Truett Theological Seminary & Yes & $\begin{array}{l}\text { Doctoral Universities: } \\
\text { Higher Research Activity }\end{array}$ & Private not-for-profit \\
\hline Brigham Young University & No & No & Yes & $\begin{array}{l}\text { Doctoral Universities: } \\
\text { Higher Research Activity }\end{array}$ & Private not-for-profit \\
\hline Burke Library & Yes & $\begin{array}{l}\text { Union Theological Seminary, Columbia } \\
\text { Department of Religion }\end{array}$ & Yes & $\begin{array}{l}\text { Doctoral Universities: } \\
\text { Highest Research Activity }\end{array}$ & Private not-for-profit \\
\hline Concordia Theological Seminary & Yes & 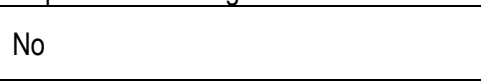 & No & $\begin{array}{l}\text { Special Focus Four-Year: } \\
\text { Faith-Related Institutions }\end{array}$ & Private not-for-profit \\
\hline Emory University & No & Candler School of Theology & Yes & $\begin{array}{l}\text { Doctoral Universities: } \\
\text { Highest Research Activity }\end{array}$ & Private not-for-profit \\
\hline Harvard University & No & Harvard Divinity School & Yes & $\begin{array}{l}\text { Doctoral Universities: } \\
\text { Highest Research Activity }\end{array}$ & Private not-for-profit \\
\hline $\begin{array}{l}\text { Jewish Theological Seminary of } \\
\text { America }\end{array}$ & Yes & No & No & $\begin{array}{l}\text { Special Focus Four-Year: } \\
\text { Faith-Related Institutions }\end{array}$ & Private not-for-profit \\
\hline Luther Seminary & Yes & No & No & $\begin{array}{l}\text { Special Focus Four-Year: } \\
\text { Faith-Related Institutions }\end{array}$ & Private not-for-profit \\
\hline Naropa University & No & Master of Divinity & Yes & $\begin{array}{l}\text { Master's Colleges \& Universities: } \\
\text { Larger Programs }\end{array}$ & Private not-for-profit \\
\hline Princeton Theological Seminary & Yes & No & No & $\begin{array}{l}\text { Special Focus Four-Year: } \\
\text { Faith-Related Institutions }\end{array}$ & Private not-for-profit \\
\hline Rice University & No & No & Yes & $\begin{array}{l}\text { Doctoral Universities: } \\
\text { Highest Research Activity }\end{array}$ & Private not-for-profit \\
\hline Temple University & No & No & Yes & $\begin{array}{l}\text { Doctoral Universities: } \\
\text { Highest Research Activity }\end{array}$ & Public \\
\hline Tufts University & No & No & Yes & $\begin{array}{l}\text { Doctoral Universities: } \\
\text { Highest Research Activity }\end{array}$ & Private not-for-profit \\
\hline $\begin{array}{l}\text { University of North Carolina at } \\
\text { Chapel Hill }\end{array}$ & No & No & Yes & $\begin{array}{l}\text { Doctoral Universities: } \\
\text { Highest Research Activity }\end{array}$ & Public \\
\hline University of Notre Dame & No & Department of Theology & Yes & $\begin{array}{l}\text { Doctoral Universities: } \\
\text { Highest Research Activity }\end{array}$ & Private not-for-profit \\
\hline Vanderbilt University & No & Vanderbilt Divinity School & Yes & $\begin{array}{l}\text { Doctoral Universities: } \\
\text { Highest Research Activity }\end{array}$ & Private not-for-profit \\
\hline Yale University & No & Yale Divinity School & Yes & $\begin{array}{l}\text { Doctoral Universities: } \\
\text { Highest Research Activity }\end{array}$ & Private not-for-profit \\
\hline
\end{tabular}


Appendix 3: Institutions Included Through Interviews Conducted by the American Theological Library Association

\begin{tabular}{|c|c|c|c|c|c|}
\hline Name & $\begin{array}{l}\text { Standalone } \\
\text { seminary }\end{array}$ & $\begin{array}{l}\text { Seminary, theology, or divinity } \\
\text { program affiliated with a } \\
\text { university }\end{array}$ & $\begin{array}{l}\text { Religious studies } \\
\text { offered through a faculty } \\
\text { of arts and sciences }\end{array}$ & Carnegie Class (Basic) & $\begin{array}{l}\text { Public/Private } \\
\text { Status }\end{array}$ \\
\hline Clark Atlanta University & No & No & Yes & $\begin{array}{l}\text { Doctoral Universities: } \\
\text { Higher Research Activity }\end{array}$ & Private not-for-profit \\
\hline Howard University & No & School of Divinity & No & $\begin{array}{l}\text { Doctoral Universities: } \\
\text { Higher Research Activity }\end{array}$ & Private not-for-profit \\
\hline $\begin{array}{l}\text { Interdenominational Theological } \\
\text { Center }\end{array}$ & Yes $^{*}$ & No & No & $\begin{array}{l}\text { Special Focus Four-Year: } \\
\text { Faith-Related Institutions }\end{array}$ & Private not-for-profit \\
\hline Spelman College & No & No & Yes & $\begin{array}{l}\text { Baccalaureate Colleges: } \\
\text { Arts \& Sciences Focus }\end{array}$ & Private not-for-profit \\
\hline University of Colorado Boulder & No & No & Yes & $\begin{array}{l}\text { Doctoral Universities: } \\
\text { Highest Research Activity }\end{array}$ & Public \\
\hline University of Oklahoma & No & No & Yes & $\begin{array}{l}\text { Doctoral Universities: } \\
\text { Highest Research Activity }\end{array}$ & Public \\
\hline
\end{tabular}

${ }^{*}$ The Interdenominational Theological Center is a consortium of six seminaries 


\section{Appendix 4: Participating Institutions: Detailed Descriptions}

The following descriptions were provided by the researchers from the participating teams as a fuller elaboration of the scope of religious studies at their institutions.

\section{Asbury Seminary}

In 1923, Henry Clay Morrison began Asbury Theological Seminary with a class of three students and fashioned a seal for the Seminary which audaciously reads "The Whole Bible for the Whole World." Nearly 100 years later, those three students number in the tens of thousands with a second full campus in Orlando, Florida. Asbury Seminary graduates flourish in every state, on every continent, in every time zone, reaching the world through evangelism, missions, church planting, preaching, teaching, and counseling.

Today, Asbury Theological Seminary is a multi-denominational, evangelical seminary serving nearly 100 different denominations. Rooted in the Wesleyan tradition with a strong emphasis on the Bible, spiritual formation and discipleship. As such, Asbury Seminary is a community called to prepare theologically educated, sanctified, Spiritfilled men and women to evangelize and to spread scriptural holiness throughout the world through the love of Jesus Christ, in the power of the Holy Spirit and to the glory of God the Father (http://asburyseminary.edu/about/theological-orientation/ourmission/).

Asbury Seminary is committed to historic Christian faith in the Wesleyan tradition in a way which is globally engaged, spiritually formative, and missionally alert. Asbury Seminary's values and strategic vision include:

1. Asbury Seminary will be committed to serving the global Church.

2. Asbury Seminary will be committed to graduate-level theological education which is faithful to God's Word.

3. Asbury Seminary will be committed to personal and community formation.

4. Asbury Seminary will be committed to pursuing a diverse, missionally oriented student body.

5. Asbury Seminary will be committed to lifelong learning for pastors and church leaders.

6. Asbury Seminary will be committed to equipping pastors for missional engagement in service to the Church.

7. Asbury Seminary will be committed to serving the emerging ethnic churches. 
8. Asbury Seminary will be committed to developing new constituencies.

9. Asbury Seminary will be committed to the laity.

10. Asbury Seminary will be committed to strengthening our economic model and developing our network of support.

The faculty at Asbury Seminary are engaging instructors, innovative thinkers, rigorous researchers and accomplished writers. They are committed to seeing students excel academically, but more importantly they desire to see a maturing of spiritual growth and formation. The multicultural faculty totals 201 people, including visiting and affiliate professors, represent eight Protestant denominations, and come from various cultures and backgrounds, from church planting to graduates of medical school. During any given year, one-third of them are teaching abroad, making them well prepared to teach students with a global perspective. The faculty has also helped lead the way in developing online education. Asbury Seminary was one of the first institutions of its kind to offer online classes.

\section{Baylor University}

Baylor University's Department of Religion describes itself as a community of faculty, staff, and students working together to address "issues of religious identity..., formation for ministry, and preparation for careers in higher education." The faculty teach courses in the Old and New Testaments, Church History, and Theology. Programs are offered to undergraduates to major or minor in Religion, and to graduate students interested in a deeper academic research approach, the MA and $\mathrm{PhD}$ programs are available.

Truett Theological Seminary has a mission to prepare women and men for full-time Christian ministry, many of whom serve in the Baptist tradition. The Seminary faculty covers the areas of biblical studies, systematic theology and practical theology in masters' level programs. While several of the faculty teach in exactly the same areas as the Religion Department, Truett's purpose is focused upon graduate education for the professional development of pastors, teachers, missionaries and religious leaders

\section{Brigham Young University}

We are similar to academic religious studies programs in that we offer courses at BYU in Israelite history, the Synoptic Gospels, Greek New Testament special topics, biblical (or near eastern) archaeology, several Ancient Near Eastern studies courses (both history and "religious studies"), the Bible as literature, etc. etc. However, we do not offer an undergraduate degree in "religious studies." 
As for the Religious Education department, we are similar to theological seminaries in that we offer scripture classes from the perspective of both scholarship and religious devotion. Moreover, Religious Education offers two master's degrees: one for LDS chaplains and one for current Mormon day-school instructors (high school age). Both of these are similar to an M.T.S. (Master of Theological Studies) offered by most seminaries.

\section{Columbia University}

The Burke Library at Union Theological Seminary is part of the Columbia University Libraries system. The Burke serves many different constituencies, including Union Theological Seminary, Columbia University, Barnard College, New York Theological Seminary.

\section{Union Theological Seminary}

Degrees conferred: MA, MDiv, STM, PhD

Brief summary: UTS was founded in 1836 by Presbyterians. It is now inter/multidenominational and has a growing number of students and faculty from other religious traditions (e.g., Islam, Judaism, Buddhism) as well as those who identify as non-religious.

Mission statement: "Union Theological Seminary in the City of New York is a seminary and a graduate school of theology established in 1836 by founders 'deeply impressed by the claims of the world upon the church.' Union prepares women and men for committed lives of service to the church, academy, and society. A Union education develops practices of mind and body that foster intellectual and academic excellence, social justice, and compassionate wisdom. Grounded in the Christian tradition and responsive to the needs of God's creation, Union's graduates make a difference wherever they serve" (https://utsnyc.edu/about/mission-vision/).

\section{Columbia University, Department of Religion}

Degrees conferred: BA (with religion major), MA, PhD

Brief summary: Founded as King's College in 1754, Columbia is a private university with a Department of Religion that undertakes the academic study of religion from a variety of critical perspectives, including multi-disciplinary approaches. 
"The Department of Religion is committed to the rigorous exploration of the growth and development of religious traditions, their historical and contemporary influence in shaping cultures and societies, and their wide-ranging roles in shaping changing global contexts. Students learn approaches with which they can understand the dynamics through which religion and religions influence society in far-reaching and far-ranging ways, from the most intimate relations of religion and the body to the most fraught relations in geo-political conflicts past and present" (http://religion.columbia.edu/undergraduate/handbook/introduction).

\section{Barnard College, Department of Religion}

Degrees conferred: BA (with religion major and minor)

Brief summary: Founded in 1889, Barnard is a private women's liberal arts college affiliated with Columbia University. Barnard has a Department of Religion that undertakes the academic study of religion (histories, texts, and practices) from a variety of approaches, including theories regarding race, class, gender, ethnicity, and other categories of affiliation and identification.

"The Religion department's curriculum offers students the opportunity to explore the histories, texts, and practices of many of the world's religious communities and to consider both the profound ways in which religion has worked historically and how it continues to inform and affect the cultural, political, and ethical debates of the current moment. In addition, our classes invite students to reflect on the vexing theoretical questions that are generated by the category "religion" itself, an abstract category that has its own complicated history. The academic study of religion is self-consciously interdisciplinary, drawing upon the methods and insights of literary studies, historiography, social analysis, and cultural comparison. Moreover, the study of religion reminds us that religious identities demand sustained critical analysis, intersecting complexly as they do with race, class, gender, and ethnicity, among other categories of affiliation and identification. In its teaching, research projects, and public programming, the Religion department promotes engaged intellectual inquiry into the rich diversity of religious institutions, rituals, ideas, and communities both past and present" (https://religion.barnard.edu).

\section{Concordia Theological Seminary}

The nature of research being done at Concordia Theological Seminary Fort Wayne (CTSFW) is reflective of our identity as a seminary of the Lutheran Church Missouri Synod. Our interviewees represent a sampling of one-third of our faculty across the four 
theological departments of our campus (Historical, Exegetical, Pastoral Ministry and Missions, and Systematic). The research supports teaching in the seminary as well as works for the Church, from narrative histories and biographies, to commentaries on books of the Bible, to contributions to confessional Lutheran dogmatics. The methods used are primarily historical, textual, grammatical, lexical, normative, constructive, and confessional.

Our Faculty identify clearly with our Vision: "CTSFW is a vibrant, Christ-centered theological community that engages and resources the church and world, domestically and internationally, with distinctively Lutheran teaching, practice and worship."

CTSFW degree programs include Master of Divinity, Master of Arts in Deaconess Studies, Master of Arts, Master of Sacred Theology, Doctor of Ministry, and Doctor of Philosophy (Missiology).

\section{Emory University}

Emory University notes in its mission statement (http://president.emory.edu/university leadership/university mission.html) the importance of the study of religion. The primary departments for the study of religion are the Undergraduate Department of Religion (http://religion.emory.edu), the Candler School of Theology (http://candler.emory.edu), and the Graduate Division of Religion (http://gdr.emory.edu). Religion courses are not required of Emory undergraduates, but courses do count for many general education requirements, and the department is popular for majors and non-majors. The Undergraduate Department has courses in theoretical approaches to religion as well as the practices and traditions of most major faiths, with robust offerings in Christianity, Judaism, Islam, Hinduism, and Buddhism.

Candler School of Theology is one of thirteen seminaries of The United Methodist Church. Alongside this affiliation, the faculty and staff represent a broad range of religious traditions, though almost exclusively within Christianity. Candler offers six single degrees and ten joint degree programs with law, business, public health, international development, bioethics, and social work. Most of the students at Candler pursue the Master of Divinity degree, with most moving into parish ministry after graduation. The curriculum and faculty of the school are divided into four, roughly equal-in-size, areas: Biblical Studies, History and Interpretation of Christianity, Christianity and Culture, and Church and Ministry.

The Graduate Division of Religion is a unit of Emory's Laney Graduate School and comprises more than 90 Emory faculty, drawn from areas of the university such as the 
School of Theology, the School of Law, the Department of Religion, and the Tam Institute for Jewish Studies. The GDR grants PhDs only, and in the following nine areas: American Religious Cultures; Ethics and Society; Hebrew Bible; Historical Studies in Theology and Religion; Jewish Religious Cultures; New Testament; Person, Community, and Religious Life; Theological Studies; and West and South Asian Religions.

There are also several interdisciplinary programs that connect to the study of religion at Emory. These include the Center for the Study of Law and Religion (http://law.emory.edu/cslr), the Emory Center for Ethics (http://www.ethics.emory.edu), and the Tam Institute for Jewish Studies (http://www.js.emory.edu), among others.

\section{Harvard University}

Founded in 1636, Harvard's concern with religion is as old as the college itself. College founders hoped the school would advance learning so as not "to leave an illiterate ministry to the churches" in succeeding generations. The oldest professorship at Harvard is the Hollis Professor of Divinity, dating from 1721. From the earliest days of the college, through the 18th century, graduates who aspired to ministry would apprentice themselves to an experienced practitioner.

The first formal graduate program at Harvard University for ministers was begun in 1811. In 1816, Harvard Divinity School (HDS) was founded -- with the support of leaders in the nascent American Unitarian movement -- as a nonsectarian theological school. In the 19thc century that meant the student body included Protestant Christians of several traditions. In the 21st century, the faculty and student body represent about 30 different faiths and Christian denominations, as well as many nationalities.

The tradition of professional ministerial education continues in the Divinity School through the M.Div. degree, and the school offers three additional graduate degree programs: M.T.S. and Th.M., and Ph.D. The doctoral program is offered jointly with the Committee on the Study of Religion in Harvard University's Faculty of Arts and Sciences.

Instructors in the Committee on the Study of Religion are drawn equally from the Arts and Sciences faculty and the Divinity faculty. In addition to overseeing joint Ph.D. program with HDS, the Committee also administers the undergraduate program in religion. Diverse departments are represented on the Committee, and students may find themselves working with professors in very different fields during their program of study. 
All ten faculty in our sample have standing in the Committee on the Study of Religion. Of these, all but one professor has a primary appointment at the Divinity School.

\section{Jewish Theological Seminary of America}

The Jewish Theological Seminary (JTS) was founded in 1886 through the efforts of two distinguished rabbis, Dr. Sabato Morais and Dr. H. Pereira Mendes, along with a group of prominent lay leaders from Sephardic congregations in Philadelphia and New York. Its mission was to preserve the knowledge and practice of historical Judaism. In 1887, JTS held its first class of ten students in the vestry of the Spanish-Portuguese Synagogue, New York City's oldest congregation.

Since then, JTS has greatly expanded its mission, creating a beautiful campus and evolving into the prestigious center of Jewish learning it is today. A Jewish university with a world-class faculty and a diverse student body, JTS grants undergraduate, graduate, and professional degrees through its five schools and offers enriching programs for the Jewish community in the United States, Israel, and around the world.

JTS schools include the Gershon Kekst Graduate School; The Rabbinical School; H. L. Miller Cantorial School and College of Jewish Music; William Davidson Graduate School of Jewish Education; and Albert A. List College of Jewish Studies..

The Gershon Kekst Graduate School offers the most extensive academic program in advanced Jewish studies in North America. The Kekst Graduate School awards master's and doctoral degrees in numerous areas of specialization, ranging from Ancient Judaism to Modern Jewish Studies and from Jewish Gender and Women's Studies to Jewish Ethics. Students delve deeply into their chosen areas of focus while acquiring broadbased knowledge of the Jewish experience.

At The Rabbinical School we train the head, the heart, and the hands. We are a modern yeshiva, offering intensive study of classical texts in an egalitarian setting. We are a university with world-class scholars devoted to critical inquiry. And we are a cutting-edge professional school, training students to be transformative Jewish leaders.

Cantors bring meaning and beauty to worship and punctuate the life cycle through music. H. L. Miller Cantorial School and College of Jewish Music is the single most comprehensive accredited program in Jewish liturgy and nusah (the musical modes and melodies by which the liturgy is expressed) available in North America. Our deep training in Jewish music is complemented by innovative approaches to prayer, 
spiritual leadership, and education that prepare students to shape joyful and soulful Jewish communities.

The William Davidson Graduate School of Jewish Education trains the leaders who will shape the lives and communities of the Jewish people for decades to come. The Davidson School is the largest pluralistic school of Jewish education in North America. For over a century, we have graduated leaders who go on to define the field of Jewish education and shape Jewish experience in schools, start-ups, congregations, nonprofits, and beyond.

Students at List College pursue a rigorous, synergistic, and rewarding curriculum in Jewish studies at JTS, and in the liberal arts and sciences at either Columbia University or Barnard College. Each List College student pursues a comprehensive core curriculum in Jewish Studies, and chooses a major field in which to specialize. Majors can range from Bible to Modern Jewish Studies, and from Jewish Ethics to Midrash.

\section{Luther Seminary}

Religious studies at Luther Seminary is focused on preparing leaders to serve in Christian communities. Full-time faculty have deep engagements within particular Christian traditions (particularly Lutheranism) and many are ordained clergy in those traditions. While focused on the Christian tradition, the Seminary encourages engagement with interfaith settings as well as practitioners and scholars from other faiths. Luther Seminary offers the following degrees: Master of Divinity, Master of Arts in Children, Youth, and Family Ministry, Master of Arts in Christian Ministry, Master of Arts in Leadership and Innovation for Ministry, Master of Arts (Academic), Master of Arts (Studies in Lutheran Ministries), Master of Theology, Doctor of Philosophy, and Doctor of Ministry.

The scholarship and teaching scope of the faculty is organized around Bible, history, theology, and leadership. Faculty make use of broader methodologies and various cognate disciplines such as philosophy, sociology, cultural studies, history, political science, law, rhetoric, anthropology, etc. In addition to writing for other scholars, many faculty strive to translate their scholarship in ways accessible to clergy, lay persons, and the general public through blogs, websites, journalistic venues, and localized presentations. 


\section{Naropa University}

At Naropa University the study of religion falls into the Department of World Wisdom Traditions, which contains both religion and traditional Eastern arts. On the undergraduate level students study contemplative religious traditions utilizing the Religionswissenschaft methodology and study most major religious traditions (Christianity, Judaism, Islam, Buddhism, Taoism, and Hinduism) in a non-comparative manner.

On the graduate level, there are several option of focus. There is an option to study Contemplative religions similar to the undergraduate program. However, the majority of graduate students major in Indo-Tibetan Buddhist studies. Within the Buddhist studies program, one can choose one of two tracks: History of Religions, which follows the Religionswissenschaft methodology, or Tibetan Traditions, which utilizes a pedagogical method similar to a shedra, which is the Tibetan monastic educational system. The two tracks overlap for some courses and are distinct in others. Finally, Naropa University also offers a Master of Divinity degree. Students working on an MDiv have the option to focus as well; they can choose to focus on contemplative religions or focus on the Tibetan Traditions method. The option to add a language concentration in Sanskrit or Tibetan is also available to all graduate programs.

\section{Princeton Theological Seminary}

Princeton Theological Seminary prepares women and men to serve Jesus Christ in ministries marked by faith, integrity, scholarship, competence, compassion, and joy, equipping them for leadership worldwide in congregations and the larger church, in classrooms and the academy, and in the public arena. A professional and graduate school of the Presbyterian Church (U.S.A), the Seminary stands within the Reformed tradition, affirming the sovereignty of the triune God over all creation, the Gospel of Jesus Christ as God's saving word for all people, the renewing power of the word and Spirit in all of life, and the unity of Christ's servant church throughout the world. This tradition shapes the instruction, research, practical training, and continuing education provided by the Seminary, as well as the theological scholarship it promotes.

In response to Christ's call for the unity of the church, the Seminary embraces in its life and work a rich racial and ethnic diversity and the breadth of communions represented in the worldwide church. In response to the transforming work of the Holy Spirit, the Seminary offers its theological scholarship in service to God's renewal of the church's life and mission. In response to God's sovereign claim over all creation, the Seminary seeks 
to engage Christian faith with intellectual, political, and economic life in pursuit of truth, justice, compassion, and peace.

\section{Rice University}

Rice University's Department of Religion consists of 13 full-time faculty, one adjunct professor, and four affiliated faculty (Professors of Anthropology, Philosophy and Sociology). The department has a broad range of research interests and teaching topics, including (but not limited to) African and African American religions, Buddhism and Buddhist thought, ancient and modern Judaism and Christianity, colonial and modern Hinduism, religion and psychology, and modern American religions. There seems to be a special emphasis on the more uncommon or unknown aspects of many religions within the department, with studies in apocrypha, mysticism and gnosticism being quite common among faculty. The methods used by members of the department are historical, literary, philosophical and social-scientific in nature.

The department offers a certificate program in Gnosticism, Esotericism, and Mysticism (GEM) which provides students with a theoretical framework in the often marginalized, more esoteric elements of religion. The goal is to include diverse voices from religious traditions, as opposed to focusing on orthodox traditions. There is also an interdisciplinary program at Rice in the Study of African American Religions, which brings together faculty from the departments of Religion, History, Sociology and English that are concerned with the impact and development of African American Religion in the United States. The program has a very broad focus and there are about 11 graduate students affiliated with this program.

The Religion department is housed in the Humanities building on campus, along with the Philosophy and History departments. The department also hosts the Religious Studies Review (RSR), a publication for short reviews and longer review essays for most religious studies publications. There are undergraduate and graduate degrees in Religion available at Rice, with 38 current graduate students. While there are some junior faculty members, the majority are more senior and have been at Rice University for quite some time.

\section{Temple University}

The Temple Religion Department was established in 1961, having grown out of a previous school of theology in the Baptist tradition. From its beginning the department has been unaffiliated with any particular faith, developing deep roots in interreligious dialogue and interdisciplinary methods in the study of religion. An early focus on the 
three monotheistic religions - Christianity, Judaism, and Islam - soon broadened to include non-Western religions and more general religious studies topics such as the death and dying awareness movement, sports and religion, and gender and religion. Today the Temple University Religion Department includes scholars specializing in Islam, early Christianity, Biblical studies, American Judaism, Japanese, Chinese, and Tibetan Buddhism, Afro-Caribbean religions, and the intersection of religion and secular society.

With 19 tenured, tenure-track, and non-tenure track faculty, the Temple Religion Department offers the B.A., M.A., and Ph.D. degrees. Undergraduates can also minor in religion or Jewish studies. The department maintains close ties with religious institutions of varying faith traditions, both locally and globally. The faculty are actively engaged in research and annually produce many articles and books in addition to maintaining a busy teaching schedule. The 2015 Student Profile listed the Religion Department as having 17 undergraduate majors and 54 graduate students. Despite the low number of undergraduate majors, the department reaches a very large number of students through the University's general education program. Since 2005, the Religion Department has awarded over 30 Ph.D. degrees.

\section{Tufts University}

Tufts University's Department of Religion, part of the School of Arts and Sciences, consists of five tenured faculty and two senior lecturers. The department does not offer graduate degrees. Arts and Sciences undergraduates can major or minor in Religion. School of Engineering undergraduates can minor in Religion.

The department was until a few years ago the Department of Comparative Religion. As such, the representation of global issues and non-Christian traditions is strong. Faculty have scholarly and teaching interests in Buddhism, Hinduism, Islam, early Christianity, and American religious history. They actively contribute to programs in the Consortium of Studies in Race, Colonialism, and Diaspora at Tufts (which includes Africana Studies, American Studies, Asian American Studies, US Latino Studies, and Colonialism Studies).

\section{University of North Carolina at Chapel Hill}

Founded in 1946, the UNC Department of Religious Studies was one of the first to be created in a state university. In that year, James A. Gray, president of R. J. Reynolds, endowed a professorship in biblical literature out of a desire to impart "the fundamentals of the Bible" to undergraduates. Popular scholar and teacher Bernard Boyd filled this 
chair from 1950 to the early 1970s. Around the same time, philosopher-sociologist Arnold Nash was hired to chair the fledgling department.

The department expanded in the 1960s and 1970s, bringing on new faculty who represented a growing array of interests within religious studies. These included the ancient Near East, medieval studies, religion and literature, philosophy of religion, psychology of religion, Buddhism, Hinduism, and African religions. At this stage, the department was devoted primarily to undergraduate instruction, an area in which the department has continued to excel. An M.A. program was created in 1978 and a Ph.D. program in 1985 .

At present, the faculty conduct research and teach courses in a number of religious traditions, including Christianity, Judaism, Islam, and Buddhism. They analyze religious life from the ancient and modern world, from ancient Sumer to present-day Iran, from early modern Europe to 21st-century India, from medieval Japan to contemporary America. They are trained in an enormous variety of scholarly methods, including textual studies and literary theory, history, ethnography and other social sciences, law, philosophy and theology, archaeology, and critical cultural theory. With this breadth of training, our faculty is equipped to offer students a range of skills that are invaluable for the exploration of human history and culture.

Today, the UNC Department of Religious Studies is dedicated to the study of religions as historical and cultural phenomena. It takes an interdisciplinary approach to understanding religious traditions from around the world: their history, sacred texts, beliefs, rituals, and institutions.

Because religious pluralism plays an important role in teaching the value of diversity, the Department is committed to bringing a broad range of perspectives into the study of religion. UNC offers B.A., M.A., and Ph.D. programs in Religious Studies; undergraduate minors in Religious Studies, Christianity and Culture, Islamic and Middle Eastern Studies, and Jewish Studies; an honors program for undergraduate majors; as well as frequent public lectures and continuing education seminars that advance the academic study of religion. Students receive training that equips them for an enormous variety of careers-in law, medicine, teaching, business, social service, journalism, politics, the arts, and more.

Courses having religious studies themes are taught in many other curricula of the University, including the Departments of Classics, Anthropology, History, Philosophy, Sociology, Social Medicine, and Germanic and Slavic Languages, and many of the faculty teaching these are also named affiliated faculty in the Dept. of Religious Studies. 
There are also two independent study centers:

The Carolina Center for the Study of the Middle East and Muslim Civilizations, promoting understanding of the Middle East through teaching, research, and community outreach.

The Carolina Center for Jewish Studies, an academic program more integrated into the liberal arts than many Jewish Studies programs created at peer institutions. Jewish Studies is a highly interdisciplinary field that concerns itself with the history, culture, and religious traditions of Jews in their interactions with others from the ancient period to the present. It draws faculty strength from religious studies, history, languages and literatures, archaeology, political science and other disciplines in the humanities and social sciences.

\section{University of Notre Dame}

The University of Notre Dame carries the reputation for being an excellent place to do religion because of the freedom the institution affords and protects to explore all aspects of religion. The core of the study of religion resides in the mission statements of the University and the large Department of Theology, and is reflected in areas of faculty and research strength in theology, religious history, religion and literature, religion and politics, and sociology of religion. In addition to these disciplinary strengths, multiple interdisciplinary centers and colloquia deal broadly with religion, drawing heavily on history, sociology, political science, Asian studies, and of course theology. Strong graduate programs exist in all these disciplines, and the centers and colloquia provide graduate students and faculty a rich intellectual environment.

\section{Vanderbilt University}

Scholars of religion at Vanderbilt are dispersed across multiple departments and schools. The majority are shared between the Divinity School and the School for Arts \& Sciences. Needless to say, all faculty connected with the Divinity School work on religion to some extent, specifically in the Judeo-Christian tradition. Within the School for Arts \& Sciences, faculty members working on religion are concentrated in the Department for Religious Studies, but can also be found in the History Department and the Asian Studies Program. This latter group of scholars works within other religious traditions, specifically Islam, Hinduism and Buddhism.

There are two, separate, graduate programs concerning religion. The first is housed in the Divinity School. It is interdenominational and focuses on training ministers. The 
Divinity School offers professional degrees in Master of Divinity and Master of Theological Studies. A separate graduate program exists as a division of the Graduate School, known as the Graduate Department of Religion. It offers an M.A. and Ph.D. in Religion. Fields of Study included in the GDR include Critical Studies in Asian, Islamic and Jewish Traditions; Ethics and Society; Hebrew Bible and Ancient Israel; Historical Studies; Homiletics and Liturgics; Jewish Studies (M.A.); New Testament and Early Christianity; Religion, Psychology and Culture; and Theological Studies. Courses offered in the Graduate Department of Religion are taught by faculty in the Divinity School, the School for Arts \& Sciences, the Law School and the Medical School, though the majority of these faculty are affiliated with the first two schools, as noted above. All scholars we interviewed were faculty in the GDR program.

\section{Yale University}

There are two major loci of study and research in Religious Studies at Yale University: the Divinity School and the Department of Religious Studies. Each views itself as having a very distinct role, the former as a professional school that "encourages scholarly engagement with Christian traditions in a global, multi-faith context" 39 and the latter as a research-oriented, Ph.D.-granting department within the Faculty of Arts and Sciences, dedicated to the study of religion worldwide.

Although the two academic units are careful to differentiate themselves, in effect, many tenured Divinity School professors are granted a secondary appointment in religious studies that entitles them to advise and train graduate students. There is an element of prestige in having an appointment in the Department of Religious Studies (or other "academic" departments such as history, art history or American studies) even though all Yale faculty go through the same exacting promotion and tenure review process. All of the scholars who participated in our study were associated with either the Divinity School, the Department of Religious Studies, or hold appointments in both.

\footnotetext{
39 "Yale Divinity School Mission Statement," Yale Divinity School, http://divinity.yale.edu/about-yds/strategicplan/bridging-faith-traditions.
} 


\section{Appendix 5: Local Reports}

While all participating institutions created reports based on the data and analysis conducted locally, the participants were given the option whether or not to disseminate their reports publicly. The following reports are publicly available:

Adams, R., Bedard, R., and Bogue, S. "Pitts Theology Library Local Report." Emory University, 2016, http://pitts.emory.edu/ithaka2016.

Bales, J. and Bales, R. "Ithaka S+R Religious Studies Project: Report of Interviews of Religion Faculty at Baylor University." Baylor University, November 1, 2016, http://hdl.handle.net/2104/9882.

Bidlack, B., Baker, M.C., and Bakkalbasi, N. "Is There Anything New under the Sun? (Ecclesiastes 1:9): A Local Report on the Research Practices of Scholars in Religion and Theology." Columbia University Academic Commons, 2016, http://dx.doi.org/10.7916/D8668DKK.

Burr, T. and Keck, A. "Faculty Research Practices at Luther Seminary." Luther Seminary, 2016, http://digitalcommons.luthersem.edu/staff pubs/1.

Cohen, I. and Steinberger, N. "Report to Ithaka Religious Studies Project.” Jewish Theological Seminary of America, November 2016, http://garfield.jtsa.edu:1801/view/action/singleViewer.do?dvs=1481045442663 220\&l ocale=en US\&VIEWER URL=/view/action/singleViewer.do?\&DELIVERY RULE ID= 10\&frameId=1\&usePid1=true\&usePid2=true.

Dearborn, V., Gundry, J., and Skrebutenas, K. The Research Practices and Support Needs of Advanced Scholars in Religion and Theology: A Local Report by Princeton Theological Seminary Library.” Princeton Theological Seminary, 2016, https://library.ptsem.edu/assessment/ithaka-2016.

Estelle-Homer, S., Krätli, G., and Richardson, C. "A Study of Faculty Research Practices in Religious Studies at Yale University.” Yale University, November 1, 2016, https://works.bepress.com/suzanne estelle-holmer/1/.

Hatch, T., Lee, R., and van Dyk, G. "Research Support Services for Religious Studies" Brigham Young University, 2016, http://scholarsarchive.byu.edu/facpub/1745. 
Hill, J. Lloyd, R., Rowland, F., and Turner, N. "Final Report: Religious Studies Scholarship at Temple University.” Temple University, 2016, https://sites.temple.edu/assessment/files/2017/o1/TempleUniversity ReligiousStudies FinalReport.pdf.

Kohut, M., Benda, C., Romero, R., Hook, B. "Research Support Services: Religious Studies." Vanderbilt University, 2016, http://hdl.handle.net/1803/8369.

Strauber, C. "Supporting the Changing Research Practices of Religious Studies Scholars at Tufts.” Tufts University, 2016, http://dl.tufts.edu/catalog/tufts:sd.0000506.

Korsman, G. and Lowrie, R. "The Research Practices of Faculty in Religious Studies: A Local Report by Harvard Library Fall 2016.” Harvard University, 2016, http://nrs.harvard.edu/urn-3:HUL.InstRepos:29503806.

Thomas, A., Tenner, E. "Research Support Services Department of Religion Rice University (Ithaka S+R Local Report)." Rice University, 2016, https://scholarship.rice.edu/handle/1911/92705.

Tippey, P.A., Horner, T., and Custer, W. "Supporting the Changing Research Practices of Religious Studies Research's.” Asbury Seminary, 2016, http://place.asburyseminary.edu/firstfruitspapers/70. 


\section{Appendix 6: Interview Guide}

1. Describe your current research focus.

2. Describe how your research is situated within the academy. [Probe for how they position themselves in relation to religious studies and theology studies and if they see their work as connecting to any other disciplines]

3. What theoretical approaches does your research utilize or rely on?

4. What research methods do you currently use to conduct your research [e.g. discourse analysis, historical analysis, etc.]?

5. Does your research produce data? If so, what kinds of data does your research typically produce? How and where do you currently keep this data? Where do plan to store this data in the long term? [Prompt: e.g. an archives, an online repository)

6. [Beyond data you produce yourself] What kinds of sources does your research depend on? How do you locate these materials?

7. Think back to a past or ongoing research project where you faced challenges in the process of conducting the research. Describe these challenges. What could have been done to mitigate these challenges?

8. How do you keep up with trends in your field more broadly?

9. If I gave you a magic wand that could help you with your research process - what would you ask it to do? [If they cite broader issues, e.g. lack of time or funding, probe further for coping strategies or workarounds they use to mitigate these challenges when conducting their research]

10. Where do you typically publish your research in scholarly settings? [Probe for kinds of publications and the disciplines these publications are aligned with] Beyond scholarly publishing are there any other venues that you disseminate your research? [Probe: e.g. blogs, popular press, classes]

11. How do your publishing practices relate to those typical to your discipline?

12. Have you ever published your research in open access venues such as open access online journals or repositories? If so, which journals or repositories and what has been your motivations for doing so? (e.g. required, for sharing, investment in open access principles). If no, why not?

13. From your perspective what are the greatest challenges and opportunities currently facing religious studies and/or theology studies?

14. Is there anything else about your research support needs that you think it is important for me that was not covered in the previous questions? 